\title{
A NEW SPECIES ALLIED TO HYLA CIRCUMDATA (ANURA: HYLIDAE) FROM SERRA DA MANTIQUEIRA, SOUTHEASTERN BRAZIL
}

\author{
Author(s): Marcelo Felgueiras Napoli \\ Source: Herpetologica, 61(1):63-69. 2005. \\ Published By: The Herpetologists' League \\ DOI: http://dx.doi.org/10.1655/03-41 \\ URL: http://www.bioone.org/doi/full/10.1655/03-41
}

BioOne (www.bioone.org) is a nonprofit, online aggregation of core research in the biological, ecological, and environmental sciences. BioOne provides a sustainable online platform for over 170 journals and books published by nonprofit societies, associations, museums, institutions, and presses.

Your use of this PDF, the BioOne Web site, and all posted and associated content indicates your acceptance of BioOne's Terms of Use, available at www.bioone.org/page/ terms of use.

Usage of BioOne content is strictly limited to personal, educational, and non-commercial use. Commercial inquiries or rights and permissions requests should be directed to the individual publisher as copyright holder. 


\title{
A NEW SPECIES ALLIED TO HYLA CIRCUMDATA (ANURA: HYLIDAE) FROM SERRA DA MANTIQUEIRA, SOUTHEASTERN BRAZIL
}

\author{
Marcelo Felgueiras Napoli \\ Departamento de Zoologia, Instituto de Biologia, Universidade Federal da Bahia, Rua Barão de Geremoabo, \\ Ondina, 40170-290 Salvador, Bahia, Brazil; and Pesquisador Associado, Departamento de Vertebrados, \\ Museu Nacional/Universidade Federal do Rio de Janeiro, Quinta da Boa Vista, \\ São Cristóvão, 20940-040 Rio de Janeiro, Rio de Janeiro, Brazil
}

\begin{abstract}
Aвstract: Hyla circumdata (Cope, 1870) occurs in subtropical and tropical rain forests, distributed over mountain ranges of the Brazilian Plateau, mainly in the Serra do Mar and Serra da Mantiqueira ranges. Samples of the northern sector of Serra da Mantiqueira revealed distinctive characters when compared to samples from the southern sectors of Serra da Mantiqueira and Serra do Mar, which suggest that the former is a new species. The new species is characterized mainly by large size (snout-vent length $57.5-70.0 \mathrm{~mm}$ in males; 55.3-67.2 $\mathrm{mm}$ in females), absence of vocal slits in adult males, and a large tympanum.
\end{abstract}

Key words: Anura; Hylidae; Hyla circumdata species group; New species; Serra da Mantiqueira; Southeastern Brazil

Hyla CIRCUMDATA (Cope, 1870) occurs in stream habitats in Atlantic Forests and is distributed over mountain ranges of the southern and southeastern Brazilian highlands (Caramaschi et al., 2001; Frost, 2002). Among the principal ranges of the Brazilian Plateau is Serra da Mantiqueira, which starts in the State of São Paulo and goes northeastwards to the State of Espírito Santo. It is divided in sectors south and north by Paraíba do Sul river valley (Alvarenga et al., 1997). Morphological comparisons among population samples of $H$. circumdata from the northern sector of Serra da Mantiqueira with that from the southern sector, and from the Serra do Mar range, revealed distinctive characters among them, which suggest that the former is a new species, described herein.

\section{Materials and Methods}

Museum acronyms of specimens used in the descriptions or examined for comparisons follow Leviton et al. (1985), augmented by MZUFV (Museu de História Natural "João Moojen de Oliveira", Universidade Federal de Viçosa, Minas Gerais, Brazil). For additional specimens examined see Caramaschi et al. (2001).

Fifteen morphometric characters were used in the account (Fig. 1), and were recorded in millimeters. Nine measurements follow Duellman (1970): SVL (snout-vent length); HL (head length); HW (head width); ED (eye

CORRESPONDENCE: e-mail,napoli@ufba.br diameter); UEW (upper eyelid width); IOD (interorbital distance); IND (internarial distance); TD (tympanum diameter); and TL (tibia length). Thigh length (THL) follows Heyer et al. (1990). The five other remaining measurements are: END (eye-nostril distance: straight line distance from anterior corner of orbital opening to posterior margin of external naris); NSD (nostril to tip of snout distance: straight line distance from anterior corner of nostril to tip of snout); FL (foot length: distance from heel to tip of fourth toe); 3FD (third finger disk diameter: greatest horizontal distance between outer edges of third finger disk); and 4TD (fourth toe disk diameter: greatest horizontal distance between outer edges of fourth toe disk). An ocular micrometer in a Zeiss stereomicroscope was used for all variables, except for SVL, HL, HW, THL, TL, and FL, which were measured with a vernier caliper. Principal component analysis (Marcus, 1990) was used in order to summarize the degree of morphometric differences between males and females. Eigenvectors and associated eigenvalues were obtained from a variancecovariance matrix. The software JACKnifed Interactive Eigenanalysis for Windows, ver. 1.13 , was used for this purpose. I used $t$-tests to compare mean values from measurement variables of males and females. Drawings were made using a Zeiss stereomicroscope with a drawing tube. Webbing formula notation follows Savage and Heyer (1967), as modified by Myers and Duellman (1982). 


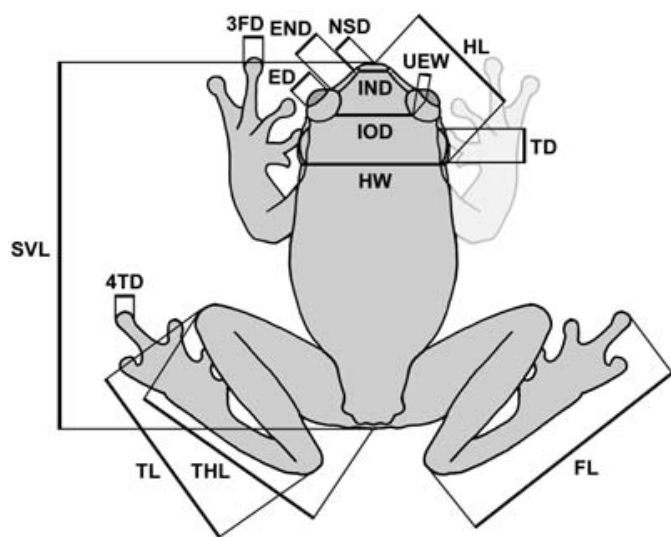

FIG. 1.-Dorsal outline of a diagrammatic tree frog with measurement variables used in the account. SVL, snoutvent length; HL, head length; HW, head width; IOD, interorbital distance; IND, internarial distance; ED, eye diameter; END, eye-nostril distance; NSD, nostril to tip of snout distance; UEW, upper eyelid width; TD, tympanum diameter; THL, thigh length; TL, tibia length; FL, foot length; 3FD, third finger disk diameter; $4 \mathrm{TD}$, fourth toe disk diameter.

\section{Species ACCount}

Hyla caramaschii sp. nov.

Hyla circumdata (Cope, 1870): Frost, 1985 (part), 2002 (part); Lutz, 1973 (part).

Holotype.-MNRJ 23701, adult male, collected on 15-16 January 1983, from Municipality of Santa Teresa $\left(19^{\circ} 56^{\prime} \mathrm{S}, 40^{\circ} 36^{\prime} \mathrm{W}\right.$; $655 \mathrm{~m}$ altitude), State of Espírito Santo, Brazil, by S. P. Carvalho e Silva, A. M. Carvalho e Silva, E. Izecksohn, and A. L. Izecksohn (Figs. 2, 3).

Paratopotypes.-MNRJ 23709-13; EI 9038, 9041, 9044, 9046-47, 9064, 9066, 9073, adult males; MNRJ 23702-08; EI 9037, 9039-40, 9042-43, 9045, 9048-50, 9065, 9067-72, 9074-88, adult females. All collected with the holotype.

Referred specimens.-Brazil: Espírito Santo: Domingos Martins (EI 9094); Fundão (MNRJ 29975). Minas Gerais: Araponga, Serra do Brigadeiro (MNRJ 23465-66; MZUFV 1632; 2748-49; 3301; 3653-56; 3680-81); Simonésia (MNRJ 21375-82; 21386-87; 23690).

Diagnosis. - Species characterized by the following combination of traits: (1) large size (SVL 57.5-70.0 $\mathrm{mm}$ in males; $55.3-67.2 \mathrm{~mm}$ in females); (2) absence of vocal slits in adult males; (3) head wider than longer in males, its width 2.7-2.8 times smaller than SVL; (4) tympanum large (TD/SVL 0.07-0.10); (5)

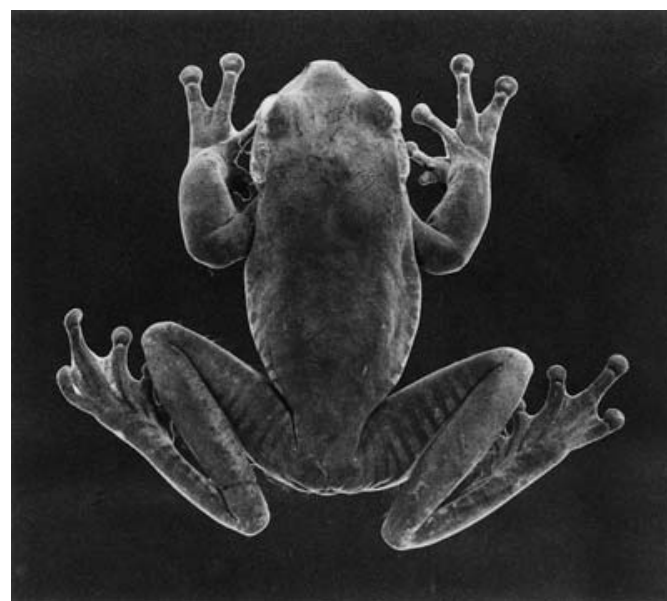

FIG. 2.-Holotype of Hyla caramaschii sp. nov., MNRJ 21356, adult male, SVL $65.0 \mathrm{~mm}$.

dorsum medium to blackish brown, with transverse dark brown bars; (6) flanks, anterior, and posterior surfaces of thighs with dark transverse brown stripes.

The absence of vocal slits in adult males of Hyla caramaschii distinguish them from all but one member of the species group, with which they often occur (the exception is H. izecksohni). Hyla caramaschii is larger than $H$. astartea, H. ibitipoca, H. izecksohni, H. nanuzae, $H$. sazimai, and $H$. ravida (SVL $30.1-50.9 \mathrm{~mm}$ in adult specimens). Dorsum blackish brown or with transverse dark brown stripes in H. caramaschii, while in H. ibitipoca and H. sazimai it is cream color, the latter with reticulated thin brown stripes and random brown dots over it; also, $H$. gouveai, $H$. carvalhoi, and $H$. astartea have immaculate dorsa (the latter with dorsal surfaces goldenbrown), and $H$. nanuzae lacks distinct transverse brown bars over it. Anterior and posterior surfaces of thighs have transverse brown stripes in $H$. caramaschii, they are immaculate in H. nanuzae, and with thin and fragmented stripes in $H$. carvalhoi. The large tympanum distinguishes $H$. caramaschii (TD/ SVL, males 0.08-0.10; females 0.07-0.09) from $H$. astartea (TD/SVL 0.04-0.06), $H$. gouveai (TD/SVL, males 0.06-0.07; females 0.06-0.08), H. hylax (TD/SVL, males 0.050.07; females 0.05-0.06), H. ibitipoca (TD/ SVL 0.06-0.07), and H. ravida (TD/SVL 0.06$0.08)$; also, from adult males of $H$. carvalhoi 

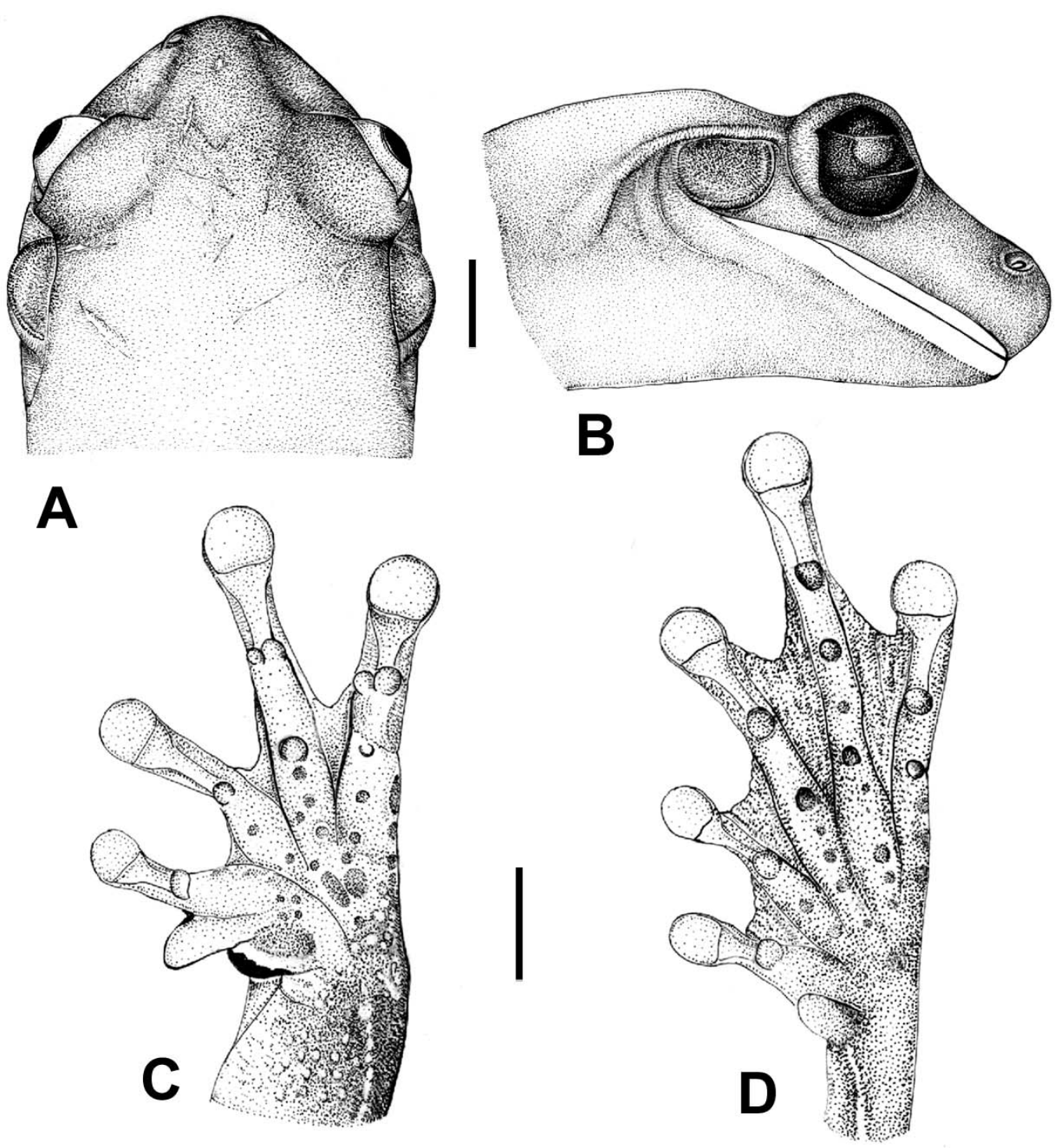

FIG. 3.-Hyla caramaschii sp. nov., MNRJ 21356, holotype, adult male. (A) Dorsal and (B) lateral views of head; (C) hand, and (D) foot. Vertical line equals $5 \mathrm{~mm}$.

(TD/SVL 0.05-0.06), H. circumdata (TD/SVL 0.06-0.09), H. nanuzae, and $H$. sazimai (combined species TD/SVL 0.06-0.07). The narrower head distinguishes males of $H$. caramaschii (SVL/HW 2.7-2.9) from males of $H$. ravida (SVL/HW 2.5-2.7). Males of $H$. caramaschii have distal tubercles of fourth finger bifid or divided, while rounded in $H$. luctuosa.
Description of adult specimens.-Descriptive statistics are presented in Table 1. Large species (SVL in males 57.5-70.0 mm; females 55.3-67.1 mm). Male head wider than long; female head length smaller $(70.2 \%)$, larger $(25.5 \%)$, or equal $(4.2 \%)$ to head width. Head width 2.6-3.0 times smaller than snout-vent length. Internarial distance smaller than eyenostril distance and eye diameter, the latter 
TABLE 1.-Descriptive statistics of adult males and females of Hyla caramaschii sp. nov. from Santa Teresa, State of Espírito Santo, Brazil. $n=$ number of specimens; $\overline{\mathrm{X}}=$ mean; $\operatorname{Min}=$ minimum; $\operatorname{Max}=$ maximum; $\mathrm{SD}=$ standard deviation.

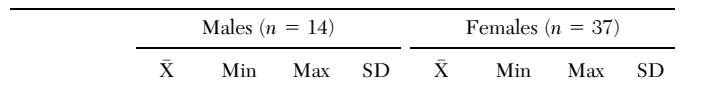

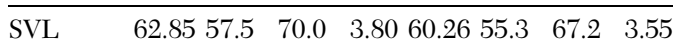

$\begin{array}{lllllllll}\text { HL } & 22.05 & 20.5 & 24.0 & 1.11 & 20.92 & 19.1 & 23.6 & 1.17\end{array}$

HW $\quad \begin{array}{llllllll}22.47 & 20.5 & 24.7 & 1.25 & 20.65 & 18.5 & 23.0 & 1.24\end{array}$

$\begin{array}{lllllllll}\text { ED } & 6.62 & 6.0 & 7.5 & 0.45 & 6.51 & 5.6 & 7.6 & 0.48\end{array}$

$\begin{array}{lllllllll}\text { END } & 5.95 & 5.3 & 6.4 & 0.35 & 5.62 & 5.0 & 6.8 & 0.40\end{array}$

$\begin{array}{lllllllll}\text { TD } & 5.46 & 4.6 & 6.2 & 0.46 & 5.01 & 4.2 & 6.0 & 0.44\end{array}$

$\begin{array}{lllllllll}\text { UEW } & 5.34 & 4.8 & 6.0 & 0.40 & 5.17 & 4.0 & 6.4 & 0.54\end{array}$

$\begin{array}{lllllllll}\text { IOD } & 6.86 & 6.0 & 7.6 & 0.44 & 6.27 & 4.8 & 7.6 & 0.55\end{array}$

$\begin{array}{lllllllll}\text { IND } & 3.85 & 3.5 & 4.3 & 0.25 & 3.49 & 3.0 & 3.8 & 0.22\end{array}$

$\begin{array}{lllllllll}\text { NSD } & 3.30 & 2.9 & 3.9 & 0.32 & 2.89 & 2.4 & 3.4 & 0.22\end{array}$

$\begin{array}{lllllllll}\text { THL } & 32.79 & 30.0 & 35.7 & 1.72 & 31.08 & 28.0 & 40.0 & 2.28\end{array}$

$\begin{array}{lllllllll}\mathrm{TL} & 32.56 & 30.0 & 35.3 & 1.58 & 31.08 & 28.8 & 35.0 & 1.59\end{array}$

$\begin{array}{lllllllll}\text { FL } & 44.73 & 42.0 & 48.5 & 2.08 & 42.10 & 38.6 & 46.6 & 2.28\end{array}$

$\begin{array}{lllllllll}3 \text { FD } & 3.10 & 2.6 & 3.7 & 0.30 & 2.80 & 2.2 & 3.4 & 0.26\end{array}$

$\begin{array}{lllllllll}\text { 4TD } & 2.97 & 2.6 & 3.4 & 0.25 & 2.61 & 2.0 & 3.2 & 0.27\end{array}$

$\begin{array}{lllllllll}\text { SVL/HW } & 2.80 & 2.68 & 2.89 & 0.07 & 2.92 & 2.72 & 3.09 & 0.08\end{array}$

$\begin{array}{llllllllll}\mathrm{ED} / \mathrm{TD} & 1.22 & 1.03 & 1.36 & 0.10 & 1.30 & 1.09 & 1.58 & 0.11\end{array}$

$\begin{array}{lllllllll}\text { TD/SVL } & 0.09 & 0.08 & 0.10 & 0.01 & 0.08 & 0.07 & 0.09 & 0.00\end{array}$

$\begin{array}{lllllllll}\text { ED/SVL } & 0.11 & 0.10 & 0.11 & 0.01 & 0.11 & 0.10 & 0.12 & 0.01\end{array}$

$\begin{array}{lllllllll}\text { THL/SVL } & 0.52 & 0.50 & 0.55 & 0.02 & 0.52 & 0.47 & 0.72 & 0.04\end{array}$

$\begin{array}{lllllllll}\text { TL/SVL } & 0.52 & 0.48 & 0.55 & 0.02 & 0.52 & 0.47 & 0.55 & 0.02\end{array}$

THL +

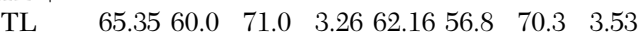

larger than eye-nostril distance. Snout rounded or slightly truncate in dorsal and lateral outlines (Fig. 3A,B). Canthus rostralis distinct. Loreal region oblique. Tympanum large, nearly circular, its width 1.0-1.4 (males) and 1.1-1.6 (females) times smaller than eye diameter. Supratympanic fold strongly visible in males, partially covering the tympanum, and weakly visible in females. Nostrils directed laterally and slightly forward. Internarial region straight, not furrowed. Vomerine teeth present in two angular patches between choanae. Vocal slits absent in males and females. Tongue ovoid, rounded or cordiform. Forearm hypertrophied, with a weak, smooth dermal fringe. Third finger disk diameter nearly equal to fourth toe disk (Fig. 3C,D). Subarticular tubercles rounded; distal tubercle of fourth finger bifid or divided in males, and bifid/divided (84.8\%) or rounded $(15.2 \%)$ in females; supernumerary tubercles present; palmar tubercle weakly developed, divided; prepollex large in males, curved, single (not bifid), and with protruding prepollical spine; modal webbing formula, I $23 / 4-2$ 3/4 II 2-3
III 2 1/2-2 $2^{+}$IV. Thigh and tibia approximately of the same length, sum of them larger than snout-vent length. Tarsus with weak, smooth dermal fringe on outer surface; no calcar. Subarticular tubercles rounded; supernumerary tubercles distinct; modal webbing formula, I 1 1/2-2 II $1^{+}-2^{+}$III $1^{+}-2$ 1/2 IV $^{+}-1^{+}$V. Belly and ventral surfaces of thighs glandular; chest, throat, and ventral surfaces of arms smooth.

Color in life.-The following description is based on the adult male MNRJ 23690, from Simonésia, State of Minas Gerais, Brazil $\left(20^{\circ}\right.$ $07^{\prime} \mathrm{S}, 42^{\circ} \quad 00^{\prime} \mathrm{W} ; 600 \mathrm{~m}$ altitude). Dorsal surfaces dark brown to blackish brown, with transverse dark brown bars on dorsum, flanks, arms, thighs, shanks, tarsus, and feet. Belly and ventral surfaces of thighs vivid yellow; chest and throat pale yellow; anterior and posterior surfaces of thighs and shanks purple with transverse dark purple bars; areas between thighs and flanks purple; ventral surfaces of arms, hands, shanks, tarsus, and feet, purple.

Color in preservative.-Dorsal surfaces medium to blackish brown, with transverse dark brown bars on dorsum, flanks, arms, thighs, shanks, tarsus, and feet. A weak brown vertebral stripe might be present from the tip of snout to the middle of dorsum. Some specimens with distinct white blotches on dorsum, elbow, knee, and above cloacae. Canthus rostralis delimited by a subcanthal dark brown stripe. Flanks pale cream with transverse dark brown bars; anterior and posterior surfaces of thighs medium brown; ventral surfaces pale cream.

Measurements of holotype (in $\mathrm{mm}$ ). $-\mathrm{SVL}$ 65.0, HL 23.2, HW 23.6, ED 6.8, END 6.2, TD 6.2, UEW 4.8, IOD 7.2, IND 4.2, NSD 3.6, THL 35.3, TL 34.5, FL 45.8, 3FD 3.6, 4TD 3.1.

Sexual dimorphism.-Adult males of Hyla caramaschii have hypertrophied forearms and enlarged prepollices, whereas adult females lack these features. I used the principal component analysis to summarize the degree of morphometric differences between males and females. Only adult specimens were sampled. The vector-correlation coefficient, which measures the similarity of size vectors for pair-wise comparisons of samples (Reis et al., 1988), was high (0.99). The first within-group principal component is a consistent measure of general 


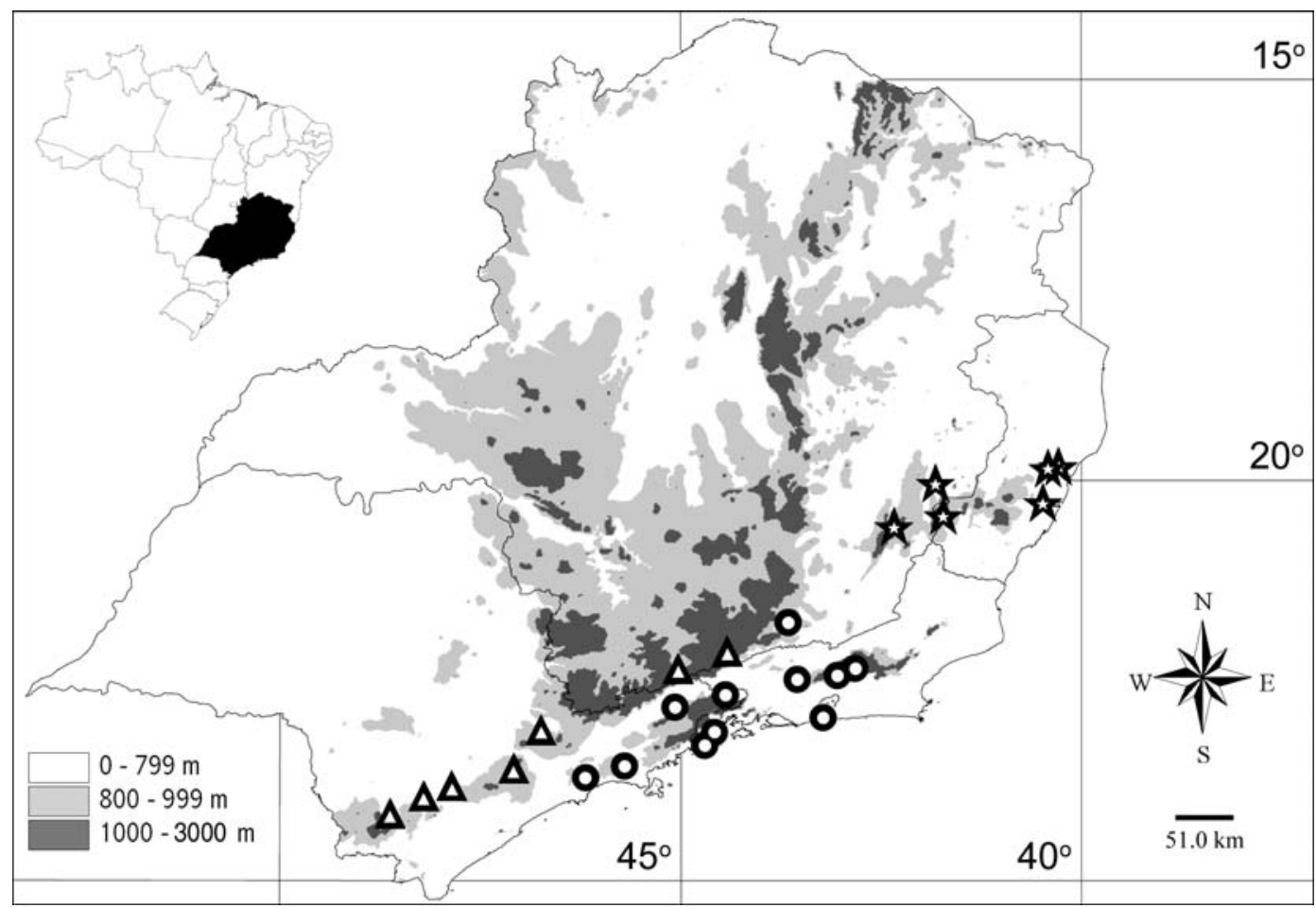

FIG. 4.-Geographic distribution of Hyla caramaschii sp. nov. (stars), H. circumdata (circles), and H. luctuosa (triangles) on topographic map. The geographic distribution of H. circumdata and H. luctuosa follows Napoli (2000).

size, with positive coefficients for all characters (Strauss and Fuiman, 1985), and accounts for $59.29 \%$ of total variance; the second axis is a consistent measure of shape, which alternates positive and negative coefficient values (Humphries et al., 1981), and accounts for $15.41 \%$ of total variance. The projection of the individual scores of both sexes resulted in a strong discrimination between them, mainly along the second axis, denoting differences in shape between males and females. The variables that most contributed to the discrimination were eye diameter and head width. The statistical comparisons for these two variables denoted that there was no statistical difference between males and females for eye diameter $(t=0.1 ; \mathrm{df}=65 ; P<0.92)$, whereas males have wider heads than females $(t=2.64$; df $=65$; $P<0.01)$. In general, females had larger tympanum diameters than males $(t=2.64$; $\mathrm{df}=65 ; P<0.01$ ).

Natural history.-Adult males (type series) from Santa Teresa, Espírito Santo, were captured calling near a forest stream (E. Izecksohn, personal communication) with gravid females.
The adult male MNRJ 29975 from Parque Municipal Pico do Goiapaba-Açu (19 54.9' S, $40^{\circ} 28.3^{\prime} \mathrm{W}, 720-850 \mathrm{~m}$ altitude), Municipality of Fundão, Espírito Santo, was captured near a mountain forest stream (J. L. Gasparini, personal communication). The adult male MNRJ 23690 from Simonésia, Minas Gerais (not calling) was collected by me near a forest stream and a temporary pond formed by rainwater, alone on a branch that was standing upright $1.8 \mathrm{~m}$ from the ground. The call of $H$. caramaschii from Santa Teresa, State of Espírito Santo, was recorded by J. L. Gasparini (inappropriate for bioacoustics analysis) and resembles the call of $H$. circumdata from Teresópolis, State of Rio de Janeiro (recorded by me; unpublished). The tadpole is unknown.

Geographic distribution.-Hyla caramaschii and allied species (H. circumdata and H. luctuosa) inhabit a complex region consisting of a relatively high plateau (Planalto Atlântico) at around 700-1000 m altitude with numerous depressions and rift valleys, and a number of mountain ranges including Serra do Mar and Serra da Mantiqueira (Fig. 4). 
Hyla caramaschii is restricted to the northern sector of Serra da Mantiqueira range, which rises to ca. $2770 \mathrm{~m}$ altitude, separated from mountains of a plateau named "Planalto Centro-Sul de Minas" by a relatively low-lying rift valley known as "Depressão do Rio Doce", and from the southern sector of Serra da Mantiqueira range by another rift valley known as "Depressão do Rio Paraíba do Sul". The latter valley extends through about $23^{\circ} \mathrm{S}$ and separates Serra do Mar mountain range, closer to the coast, from the southern sector of Serra da Mantiqueira range. As $H$. caramaschii, $H$. circumdata, and $H$. luctuosa are confined ecologically to stream habitats, covered by Tropical Atlantic forests distributed over mountain ranges, and do not cross open habitats, the referred valleys act as altimetric and ecologic barriers to the dispersion of these populations, and probably contributed as an isolation mechanism to the speciation of $H$. caramaschii. The species of the $H$. circumdata group inhabit similar ecological areas to $H$. caramaschii in southeastern Brazil (Napoli, 2000), and the pattern of distribution of these species suggests that it is correlated with uplifting of coastal mountains throughout the Cenozoic.

Etymology.-The name is a noun in the genitive case honoring Ulisses Caramaschi, for his extensive contribution to the knowledge of Brazilian herpetology.

\section{Resumo}

Hyla circumdata (Cope, 1870) se distribui em áreas de floresta tropical, principalmente nos complexos da Serra do Mar e da Mantiqueira. Amostras populacionais do setor setentrional da Serra da Mantiqueira revelaram caracteres distintivos quando comparadas a amostras do setor sul da Serra da Mantiqueira e da Serra do Mar, indicando que as primeiras constituem uma nova espécie, descrita neste trabalho. A nova espécie é caracterizada principalmente pelo tamanho grande (comprimento rostro-cloacal 57.5$70.0 \mathrm{~mm}$ em machos; 55.3-67.2 $\mathrm{mm}$ em fêmeas), ausência de fendas vocais em machos adultos e tímpano grande.

Acknowledgments.-I thank U. Caramaschi for providing space, facilities, and helpful comments during the development of this paper. I acknowledge C. A. G. Cruz, C. F. B. Haddad, E. Izecksohn, L. B. Nascimento, P. E. Vanzolini, R. N. Feio, and U. Caramaschi for allowing me to examine specimens under their care; R. Fernandes for critically reading and improving the manuscript; P. R. Nascimento for the line drawings; J. L. Gasparini for the donation of photographs and specimens of $H$. caramaschii from Fundão, State of Espírito Santo, Brazil; the Coordenação de Aperfeiçoamento de Pessoal de Ensino Superior (CAPES) for a fellowship.

\section{Literature Cited}

Alvarenga, M. A., J. E. Bezerra da Silva, and P. S. Nunes. 1997. Unidades de Relevo. Pp. 51-73. In IBGEInstituto Brasileiro de Geografia e Estatística, Recursos Naturais e Meio Ambiente: uma visão do Brasil, 2nd ed. IBGE-Departamento de Recursos Naturais e Estudos Ambientais, Rio de Janeiro, Brazil.

Caramaschi, U., M. F. Napoli, and A. T. Bernardes. 2001. Nova espécie do grupo de Hyla circumdata (Cope, 1870) do Estado de Minas Gerais, Brasil (Amphibia, Anura, Hylidae). Boletim do Museu Nacional, Nova Série, Zoologia 457:1-11.

Cope, E. D. 1870. Eighth contribution to the herpetology of tropical America. Proceedings of the American Philosophical Society 11:553-560.

Duellman, W. E. 1970. The hylid frogs of Middle America. Monograph of the Museum of Natural History, The University of Kansas 1:1-427.

Frost, D. R. 1985. Amphibian Species of the World. A Taxonomic and Geographical Reference. Allen Press and Association of Systematics Collections, Lawrence, Kansas, U.S.A.

. 2002. Amphibian Species of the World: an online reference. V2.21 (15 July 2002). Electronic database available at http://research.amnh.org/herpetology/amphibia/index.html.

Heyer, W. R., A. S. Rand, C. A. G. Cruz, O. L. Peixoto, and C. E. Nelson. 1990. Frogs of Boracéia. Arquivos de Zoologia, Museu de Zoologia da Universidade de São Paulo 31:231-410.

Humphries, J. M., F. L. Bookstein, B. Chernoff, G. R. Smith, R. L. Elder, and S. G. Poss. 1981. Multivariate discrimination by shape in relation to size. Systematic Zoology 30:291-308.

Leviton, A. E., R. H. Gibbs, E. Heal, and C. E. Dawson. 1985. Standards in herpetology and ichthyology. Part 1. Standard symbolic codes for institutional resource collections in herpetology and ichthyology. Part 2. Country/city index. Copeia 1985:802-829.

LuTz, B. 1973. Brazilian Species of Hyla. University of Texas Press, Austin and London.

Marcus, L. F. 1990. Traditional Morphometrics. Pp. 77122. In F. J. Rohlf and F. L. Bookstein (Eds.), Proceedings of the Michigan Morphometrics Workshop. Special Publication 2. The University of Michigan Museum of Zoology, Ann Arbor, Michigan, U.S.A.

Myers, C. W., and W. E. Duellman. 1982. A new species of Hyla from Cerro Colorado, and other tree frog records and geographical notes from Western Panama. American Museum Novitates 2752:1-32.

NAPOLI, M. F. 2000. Taxonomia, variação morfológica e distribuição geográfica das espécies do grupo de 
Hyla circumdata (Cope, 1870) (Amphibia, Anura, Hylidae). Ph.D. Dissertation, Universidade Federal do Rio de Janeiro/Museu Nacional, Rio de Janeiro, Brazil.

Reis, S. F., J. F. Cruz, and C. J. Von Zuben. 1988. Análise multivariada da evolução craniana em roedores caviíneos: convergência de trajetórias ontogenéticas. Revista Brasileira de Genética 11:633-641.

Savage, J. M., ANd W. R. Heyer. 1967. Variation and distribution in the tree-frog genus Phyllomedusa in
Costa Rica, Central America. Beiträge zur Neotropischen Fauna 5:111-131.

Strauss, R. E., and L. A. Fuiman. 1985. Quantitative comparisons of body form and allometry in larval and adult Pacific sculpins (Teleostei, Cottidae). Canadian Journal of Zoology 63:1582-1589.

Accepted: 7 July 2004

Associate Editor: Christopher Sheil

\title{
A NEW SPECIES OF SCINAX (ANURA: HYLIDAE) FROM MISIONES, ARGENTINA
}

\author{
Julián FaIVOVICH ${ }^{1}$ \\ Department of Herpetology, American Museum of Natural History, Central Park West at 79th Street, \\ New York, NY 10024, USA; Department of Ecology, Evolution, and \\ Environmental Biology (E3B)/Columbia University; and División Herpetología, \\ Museo Argentino de Ciencias Naturales “Bernardino Rivadavia," Buenos Aires, Argentina
}

\begin{abstract}
A new species of the Scinax catharinae group is described from Misiones, northeastern Argentina. It is characterized by the dark yellow flash colors in hidden areas of thigh and shank; robust but not hypetrophied forearm; and lack of a thick glandular patch in the inguinal region. It is closely related to Scinax berthae, from which it can be distinguished by having a more robust forearm and less toe webbing. In addition, relative to $S$. berthae, males of the new species are slightly larger and the few known females are notably larger.
\end{abstract}

Key words: Anura; Argentina; Hylidae; New species; Scinax; Scinax aromothyella; Scinax catharinae; Scinax berthae

The TREe frog genus Scinax includes 85 recognized species that occur from Mexico to east-central Argentina (updated from Frost, 2002). Nine species have been recorded from Argentina, including S. acuminatus (Cope, 1862); S. berthae (Barrio, 1962); S. castroviejoi De la Riva 1993 (but see De la Riva, Haddad, and Lasahara, 2000); S. fuscomarginatus (A. Lutz, 1925); S. fuscovarius (A. Lutz, 1925); S. granulatus (Peters, 1871); S. nasicus (Cope, 1862); S. squalirostris (A. Lutz, 1925); and S. perereca Pombal, Haddad, and Lasahara, 1995. Of these, all but $S$. berthae belong to the ruber clade, as defined by Faivovich (2002), whereas $S$.

\footnotetext{
${ }^{1}$ Correspondence: e-mail, julian@amnh.org
}

berthae is included in the S. catharinae species group of the catharinae clade. In this paper, I describe a new species of Scinax collected during fieldwork in Misiones, Argentina. The new species is the second Argentine frog that belongs to the $S$. catharinae species group.

Webbing formula follows Savage and Heyer (1967) as modified by Myers and Duellman (1982). Measurements (in millimeters) follow Duellman (1970). Abbreviations used throughout the text are SVL (snout-vent length), HL (head length), HW (head width), IND (internarial distance), ED (eye diameter), EN (eye-nostril distance), TD (tympanum diameter), TL (tibia length), and FL (foot length). Reported geographic coordinates were taken with a global positioning system 

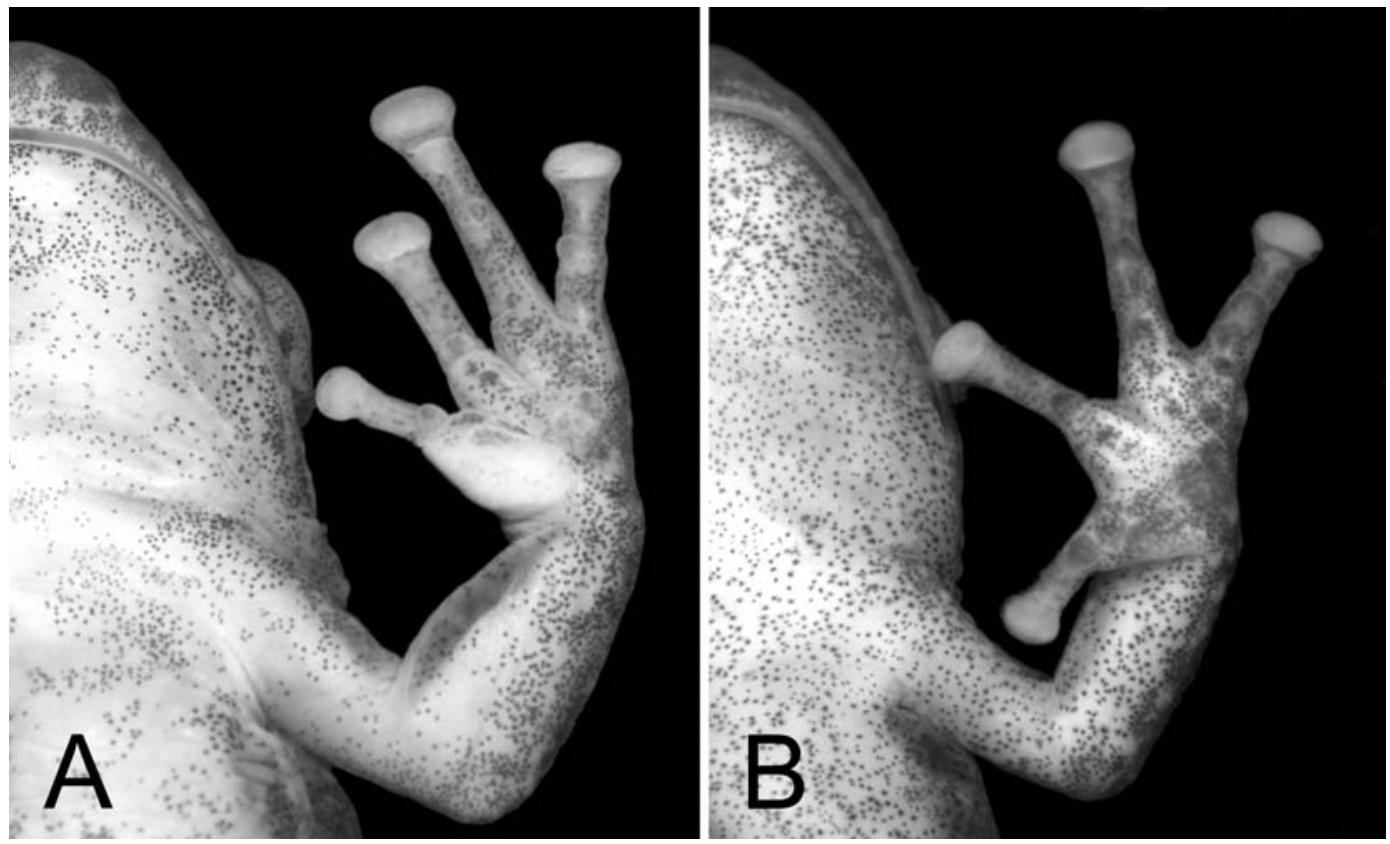

FIG. 1.-Ventral view of left arm of males of (A) Scinax aromothyella MACN 35265 (paratype), SVL 20.2 mm, (B) Scinax berthae MACN 37249, SVL $20.3 \mathrm{~mm}$.

(GPS). Sex was determined by examination of secondary sexual characters (nuptial pads, vocal slits, and expansion of the vocal sac) or, when in doubt, by examination of gonads.

In males of Scinax berthae and the new species described below, the vocal sac is more expanded and folded than those of males of other species of the $S$. catharinae group. A brief discussion of vocal sac morphology and definitions employed by previous authors, as applicable to Scinax, was included in Faivovich (2002: character 36). It should be noticed that although in that paper both $S$. berthae and the new species (as $S$. sp. 1) were coded as 36.1 (i.e., vocal sac externally evident by loose, partially expanded skin), the condition of the vocal sac could actually be different from that present in all exemplars of the $S$. ruber clade, where the skin of the vocal sac seems to be thinner.

Specimens examined are in the following collections: American Museum of Natural History (AMNH); Centro Nacional de Investigaciones Iológicas (CENAI), housed at Museo Argentino de Ciencias Naturales "Bernardino Rivadavia"; collection of Celio F. B. Haddad, Universidade Estadual Pau- lista, Rio Claro, São Paulo, Brazil (CFBH); Institut Royal des Sciences Naturelles de Belgique, Brussels, Belgium (IRSNB); Laboratorio de Investigaciones Herpetologicas, Universidad de Buenos Aires, Argentina (LIH), partially housed at Museo Argentino de Ciencias Naturales "Bernardino Rivadavia," Buenos Aires, Argentina (MACN); Museu Nacional, Rio de Janeiro, Brazil (MNRJ); Museu de Zoologia, Universidade de São Paulo, São Paulo, Brazil (MZUSP); Museo de História Natural, Universidade de Campinas, Campinas, São Paulo, Brazil (ZUEC); Departmento de Zoologia, Universidade Federal do Rio de Janeiro, Rio de Janeiro, Brazil (ZUFRJ). See Appendix I for additional specimens examined.

\section{Description of New Species}

Scinax aromothyella sp. nov.

Scinax berthae (no Barrio, 1962): Langone and Prigioni (1988) (part).

Scinax sp. 1: Faivovich (2002)

Holotype.-MACN 35278, adult male, from Argentina: Misiones: Departamento Guarany: 
San Vicente: Km 1272, Ruta Nacional 14, Campo Anexo INTA "Cuartel Rio Victoria" $\left(26^{\circ} 55^{\prime} \mathrm{S}, 54^{\circ} 25^{\prime} \mathrm{W}\right)$ Collected on 19 February 1994, by J. C. Baciluk and J. Faivovich.

Paratopotypes.-MACN 35272-35273, adult females; MACN 35262 (specimen with some superficial dissections), 35265-35271, 35274-35277, 37102-37117, adult males. Collected at the type locality on various dates.

Referred specimens.-MACN 37123 male, MACN 37124 female, from Argentina: Misiones: Departamento San Pedro: Piñalito, 20 January 1998; CENAI 1269 from Misiones: Departamento Iguazu: Villa Cabureí, 13 January 1966.

Definition and diagnosis.-A species of the Scinax catharinae species group characterized by a vocal sac somewhat differentiated externally; a moderately enlarged forearm (Fig. 1); thick, externally well differentiated inguinal gland absent; inguinal region and concealed areas of thigh and shank dark yellow in life; SVL males 20.2-24.8 $(n=28)$; SVL females 29.8-31.8 $(n=2)$.

The vocal sac is slightly distended externally, distinguishing males of $S$. aromothyella from most species of the $S$. catharinae group, with the exception of $S$. berthae, to which it is most similar. S. aromothyella differs from $S$. berthae by the robustness of the forearm (slender in S. berthae), toe webbing much less developed, and larger SVL of females $(S$. aromothyella 29.8-31.8, $n=2 ; S$. berthae 23.5-25.0, $\bar{\chi}=24.5, n=4$ ); SVL of males partially overlaps (S. aromothyella: $20.2-24.8$, $\bar{\chi}=22.7, n=28 ;$ S. berthae 17.7-22.2, $\bar{\chi}=$ $20.5, n=19$ ).

The lack of thick, externally well differentiated inguinal glands separates S. aromothyella from S. centralis Pombal and Bastos, 1996, S. hiemalis (Haddad and Pombal, 1987), and S. jureia (Pombal and Gordo, 1991). The smaller SVL of males differentiates S. aromothyella from S. albicans (Bokermann, 1967) (range 26.4-31.2, $n=10$, Carvalho e Silva, 1994), $S$. catharinae (Boulenger, 1888) (range 30.435.1, $n=5$; Carvalho e Silva, 1994), and $S$. ariadne (Bokermann, 1967) (range 32.6-35.3, $n=4$; see Bokermann, 1967). Larger males of S. aromothyella are similar in SVL to smaller males of S. longilineus (B. Lutz, 1968), and S. canastrensis (Cardoso and Haddad, 1982), whose combined SVL is 24.5-30.5 (Andrade and Cardoso, 1991; Cardoso and Haddad, 1982); these species are more robust and have a more developed supratympanic fold; the latter has several tubercles scattered on the dorsum and a more acuminate snout in dorsal view. Some overlapping occurs in male SVL between S. aromothyella and S. flavogutattus (Lutz and Lutz, 1939) (23.2-28.0, $n=10$, Carvalho e Silva, 1994), but S. aromothyella can be distinguished by having a less protruded snout in profile, color pattern, and smaller female SVL (in S. flavogutattus 38.642.8, $n=5$, Carvalho e Silva, 1994).

The larger SVL of males separates $S$. aromothyella from S. machadoi (Bokermann and Sazima, 1973) (range 14.6-17.0, $n=10$, Carvalho e Silva, 1994; see Bokermann and Sazima, 1973), S. argyreornatus (MirandaRibeiro, 1926) (range 13.5-15.8, $n=20$, Carnaval, 1997), and S. agilis (Cruz and Peixoto, 1982) (range 13.5-19.5, including females; see Cruz and Peixoto, 1982).

Reduced toe webbing separates S. aromothyella from S. ranki (Andrade et al., 1987), S. canastrensis, S. centralis, S. berthae, S. ariadne, S. heyeri (Weygoldt, 1986), S. jureia, and S. longilineus, all of which have toe webbing extending to the base of the disc on the lateral margin of Toe III and the medial margin of Toe V.

The nonhypertrophied arm differentiates Scinax aromothyella from S. brieni (De Witte, 1930), S. obtriangulatus (B. Lutz, 1973), S. trapicheiroi (B. Lutz, 1954), and S. rizibilis (Bokermann, 1964); furthermore, it differs from the latter species in having a smaller nuptial pad.

In life, a dark yellow inguinal region and hidden areas of thigh and shank distinguish Scinax aromothyella from $S$. ariadne, S. angrensis (B. Lutz, 1973), S. albicans, S. catharinae, S. kautskyi (Carvalho e Silva and Peixoto, 1991), S. trapicheiroi (all with these regions opaline green; Carvalho e Silva, 1994; B. Lutz, 1973), S. littoralis (Pombal and Gordo, 1991) (black bars on a whitish or greenish background; Pombal and Gordo, 1991), S. hiemalis and S. ranki (black blotches on a greenish background; Andrade and Cardoso, 1987; Haddad and Pombal, 1987), S. carnevalli (Caramaschi and Kisteumacher, 1991) and S. jureia (black blotches on a whitish background; Caramaschi and Kisteumacher, 

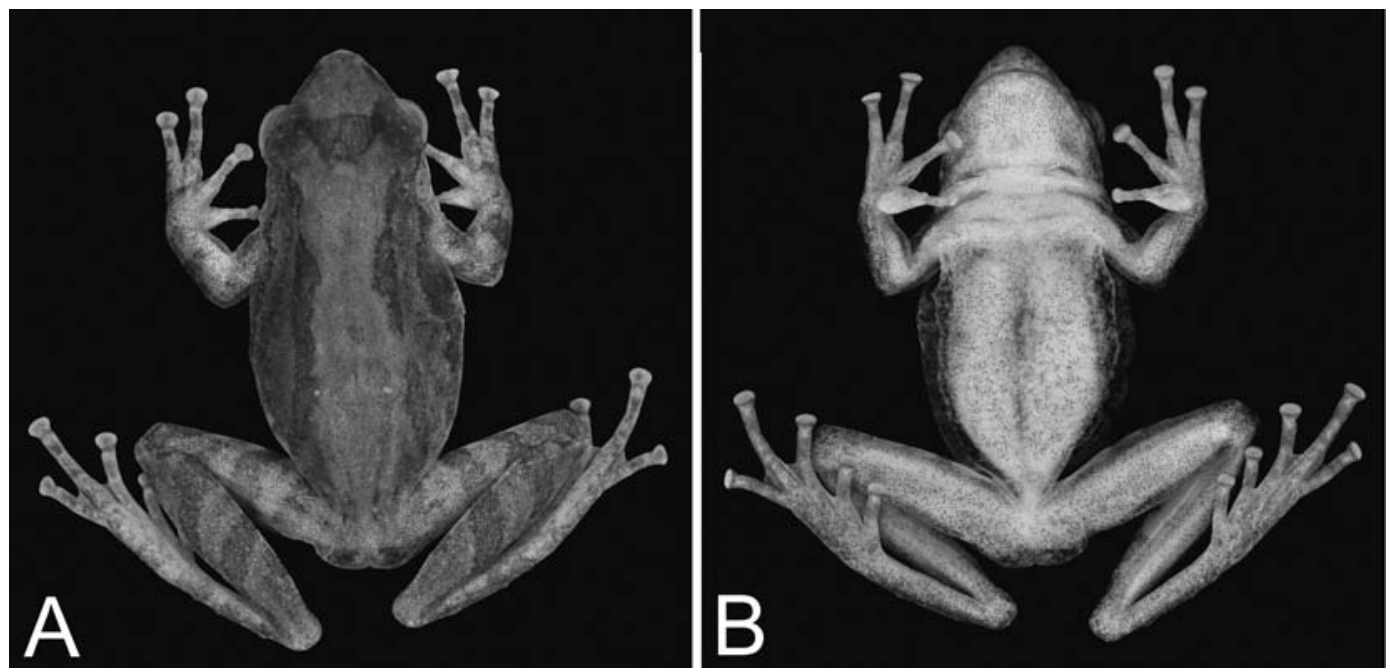

FIG. 2.-Scinax aromothyella, MACN 35278 (holotype), SVL 24.5 mm. (A) Dorsal view, (B) ventral view.

1989; Pombal and Gordo, 1991), S. luizotavioi (Caramaschi and Kisteumacher, 1991) (brown marbling; Caramaschi and Kisteumacher, 1989), S. brieni (pale blue; B. Lutz, 1973), S. humilis (B. Lutz, 1954) ("pale Nile blue to very pallid turquoise"; B. Lutz, 1973), and S. obtriangulatus ("dull grayish violet"; B. Lutz, 1973).

Description of the holotype.-Adult male (Figs. 2 and 3); body moderately robust, head nearly triangular in dorsal view, protruding in profile; head longer than wide, $32 \%$ of SVL. Nostrils slightly protruded, located laterally; distance between nostrils $43 \%$ of IOD. Tubercle between nostrils absent. Canthus rostralis rounded. Loreal region concave, forming abrupt slope toward lip. Eye large, ED 52\% of IOD, almost equal to EN. Tympanum rounded, separated from eye by distance almost equal to TD. TD $25 \%$ larger than width of disc of Finger III. Supratympanic fold poorly developed. Some scattered, flat, barely distinguishable rounded tubercles above tympanum and on eyelid. Vocal sac subgular, slightly lateralized, externally expanded. Tongue oval, free laterally and posteriorly, shallowly notched posteriorly. Vomerine teeth in two series between choanae, though slightly displaced posteriorly. Choanae elliptical. Vocal slits present, longitudinal.

Arm slender, forearm robust. Axillary membrane absent. Ulnar tubercles absent. Fingers slender; subarticular tubercles single, conical on Fingers I and II; rounded on Fingers III and IV. Palmar tubercle somewhat flat, distally bifid; thenar tubercle elliptical. discs elliptical, wider than long; disc on Finger I noticeably smaller than others. Webbing absent between Fingers III and IV, extremely reduced between Finger I and II, and II and III. Thick, unpigmented nuptial pad covering base of thumb dorsomedially, extending medially up to outer margin of the palmar tubercle, and distally up base of first phalanx. Hind limbs slender; TL $51 \%$ of SVL. A rounded, low tubercle present on heel. Toes slender; subarticular tubercles conical, those on Toe IV slightly rounded. Outer metatarsal tubercle conical, small; inner metatarsal tubercle subcircular, nearly twice as large as outer tubercle. Discs subelliptical, wider than long. Webbing formula I $2^{+}-2^{1 / 2}$ II $2-3^{+}$III $2-3^{+}$IV $3-2$ V. Tarsal fold absent. Three flat, almost indistinguishable tubercles along tarsus.

Thin, irregular patch of glandular tissue present in inguinal region. Pectoral fold absent. Anal opening at upper level of thighs. Skin on throat and dorsum smooth, granular on belly and undersurfaces of thigh.

Color in preservative.-Dorsum light brown, with an inverted dark brown trapezoid-shaped interocular mark, posterior margin notched; two irregular longitudinal wide stripes on each side, one extending dorsolat- 

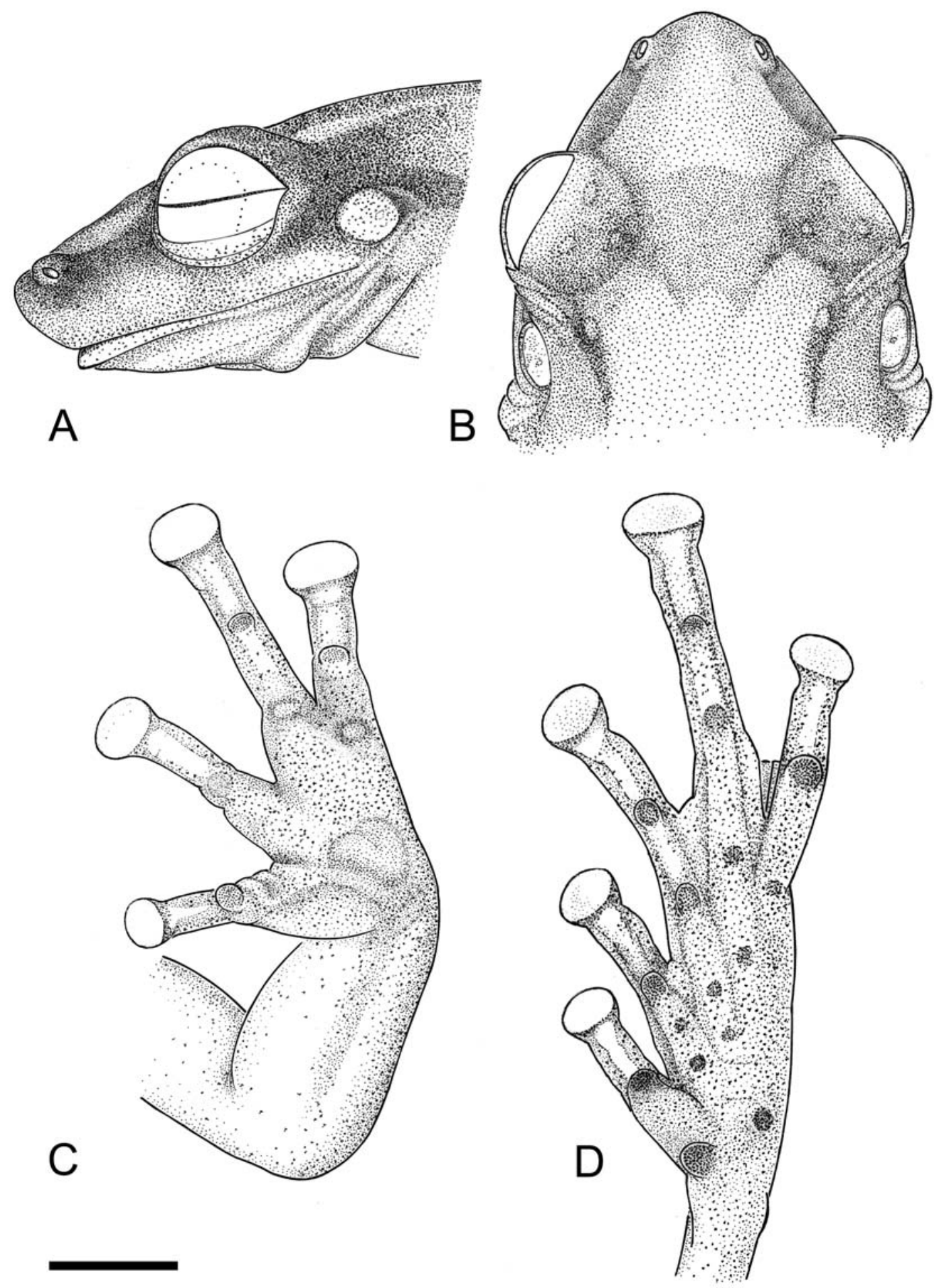

FIG. 3.-Scinax aromothyella, MACN 35278 (holotype). (A) Head, lateral view, (B) head, dorsal view, (C) left hand and forearm, ventral view, (D) left foot, ventral view. Scale $=2 \mathrm{~mm}$. 
erally from behind eye to beyond sacral region; the other, less defined, extends from posterolateral margin of eye ventrally, becoming diffuse before level of sacrum. Three dark brown diagonal bars with diffuse margins cover dorsal surface of shank, continuous to somewhat irregular, vertical bars on thigh; where marks extend to hidden surfaces and are separated by unpigmented areas. Poorly defined, irregular dark brown blotches occur on dorsal part of foot, toes, distal margin of thigh, forearm, arm, and Fingers. Venter creamy white, melanophores irregularly spaced over all ventral surfaces, including limbs, throat, belly. Inguinal region and proximal, hidden surface of thigh completely unpigmented.

Measurements of holotype.-SVL 24.5; HL 7.9; HW 7.4; IND 1.9; ED 2.4; EN 2.3; TD 1.2; TL 12.5; FL 10.5.

Variation among paratypes.-In preservative, the dorsum is lighter brown in some specimens. The width and shape of the dorsal longitudinal stripes are variable; the stripe is continuous in 21 of the 30 paratypes and discontinuous on 12 specimens. This stripe has regular margins on 16 specimens; in 8 specimens these stripes get wider at a portion posterior to the scapular region, while in four specimens, they get wider at the sacral region; in three specimens, they are expanded on both regions. In three specimens the stripes are diffuse, barely distinct. In most specimens the lateral stripe that runs from the posterolateral margin of the eye is less defined than the dorsal one; in eight of them, it diffuses just posterior to the arm, before bending posteroventrally. Twenty-five paratypes have an interocular trapezoid-shaped mark similar to the holotype, while the other four have a straight posterior margin on the trapezoid mark. In nine specimens, the vertical bars on the thigh are barely distinct, while in others the bars on the anterior and/or posterior surface of the thigh become irregular, forming an almost reticulate pattern that delimits unpigmented areas (more common on the anterior surface of the thigh) or that coalesces into a large, densely pigmented area (only on the posterior hidden surface of the thigh). In two specimens, there are two instead of three diagonal bars marks on the shank.

The ventral pattern ranges from tiny dark spots regularly scattered on the belly, throat, and undersides of limbs to a brown vermiculation on the belly, formed by aggregations of those same spots. On some specimens the spots become even denser on the undersides of the hind limbs.

In terms of morphology, most variation involves the development and presence or absence of tubercles. Some paratypes differ from the holotype by having a few rounded supernumerary tubercles on the sole (mostly at the base and along metatarsals of Toes III, IV, and $\mathrm{V}$ ) or the palm. The apparent absence of these tubercles in many specimens, including the holotype, is likely a preservation artifact. The degree of sloping of the loreal region toward the lip may be more abrupt in some specimens than in others.

The thin patch of glandular tissue in the inguinal region is visible in most specimens; however, it is not visible in a few specimens that lost pigmentation due to fixation. It is not clear if this is due to a fixation artifact or if the glandular tissue was never there. Cochran (1955) noted in Scinax brieni (as Hyla strigilata brieni) that the visibility of this character state was dependent on the quality of fixation.

The nuptial pad is present in all males, but the extent of thumb involved varies; in a few specimens some of the glands that make up the nuptial pad are also scattered along the medial margin of Finger II.

The two females are larger than males (see measurements below). Their forearms are not robust as in males, and no trace of glandular tissue is present in the inguinal region. The loreal region forms a gradual slope towards the lip in both females.

Measurements of the paratypes (mean \pm standard error, range). - Males $(n=28)$ : SVL $22.7 \pm 0.20(20.2-24.8)$; HL $7.6 \pm 0.07$ (6.88.3); HW 7.2 \pm 0.07 (6.3-7.8); IND $1.9 \pm 0.03$ (1.6-2.2); ED $2.3 \pm 0.03$ (1.9-2.5); EN $2.0 \pm$ 0.03 (1.7-2.3); TD $1.3 \pm 0.03$ (0.9-1.5); TL $12.2 \pm 0.1(11.3-13.3) ;$ FL $10.0 \pm 0.1(9.0$ 10.8). Females $(n=2)$ SVL 29.8-31.8; HL 9.8-10.4; HW 9.5-9.7; IND 2.2-2.3; ED 2.83.0; EN 2.6-2.7; TD 1.9-2.0; TL 15.4-17.0; FL 12.5-13.0.

Color in life.-Field notes of the author described color in life of referred specimens (MACN 37123-37124). The dorsal color was similar to that of the preserved specimens, although individuals turned much darker 
during the day. The ventral region was dirty white or creamy white, and the throat of calling males was yellowish. The areas that in preserved specimens appear as unpigmented in the inguinal region and hidden surfaces of thigh and shank were dark yellow. The iris was iridescent yellow, with some thin, darker reticulations. Four dark brown rays arise vertically and horizontally from the borders of the subelliptical pupil and extended to the exposed margins of the eye. While vocalizing at night, males had a lighter hue but turned darker during the day.

Natural history.-Most specimens from San Vicente were collected in open areas in semipermanent swamps, during or immediately after heavy rains, in the months of December, January, and February. Most males called from the emerging vegetation, a short distance above the water surface. The two specimens from Piñalito were collected along a stream inside the forest. In the type locality, $S$. aromothyella was found in sympatry with Bufo ictericus, Aplastodiscus perviridis, Hyla faber, H. minuta, H. semiguttata, Phyllomedusa tetraploidea, Scinax fuscovarius, S. perereca. Scinax sp. (aff. S. granulatus), Crossodactylus schmidti, Leptodactylus fuscus, L. mystacinus, L. ocellatus, Odontophrynus americanus, Physalaemus albonotatus, P. cuvieri, and Proceratophrys avelinoi.

Geographic distribution.-Scinax aromothyella is known from three localities in the province of Misiones, Argentina. The specimens treated as Scinax cf. berthae by Kwet and Di-Bernardo (1999) and by Kwet (2001) could actually be $S$. aromothyella; if this is the case, then this species might be distributed in some areas of the state of Rio Grande do Sul, Brazil.

Etymology.-The species name aromothyella is a noun in apposition, being derived from the Greek aroma (smell) + thyella (storm). The name is intended to mean "smell of the storm", alluding to the propensity of these frogs to appear during or after heavy rains.

\section{REMARKS}

The new species was included as Scinax sp. 1 in the phylogenetic analysis performed by Faivovich (2002); on the resulting mostparsimonious trees, this species appears as sister to S. berthae. The presence of glandular tissue in the inguinal region on this species was overlooked by Faivovich (2002); a review of this character state is being undertaken and will be included in a more thorough study of the phylogenetics of Scinax.

Scinax berthae is a species with a wide distribution (Barrio, 1964), ranging from São Paulo, Brazil, south to Punta Lara (the type locality) in northwestern Buenos Aires Province, Argentina, and extending west to Cerrito, Chaco Province (Langone and Prigioni, 1988; Lopez et al., 1999). It is a highly variable species, and a study to define the limits of this variation is seriously needed. B. Lutz (1973) expressed doubt concerning the identity of the two paratypes of $S$. berthae (as Hyla) from São Bernardo do Campo, São Paulo, suggesting that they could actually be $S$. rizibilis, an argument that was followed by Andrade and Cardoso (1987). While Andrade and Cardoso (1987) did not examine these paratypes, it is not clear whether B. Lutz (1973) examined them, since she based her description on the female paratype LIH 1084 (a specimen housed at the MNRJ, collected at the type locality). The paratype LIH 1088 is housed in MACN. The paratype LIH 1089 is lost (Langone and Prigioni, 1988; Varela, 1999). An examination of LIH 1088 indicates that it is morphologically indistinguishable from $S$. berthae, and is not S. rizibilis. Similar conclusions were reached by Pombal and Bokermann (Pombal, personal communication) upon comparison of specimens from São Paulo with paratopotypes.

Scinax aromothyella has been confused with S. berthae by Langone and Prigioni (1988), who cited this species from Villa Cabureí, Misiones; the specimen (CENAI 1269) is actually $S$. aromothyella.

One feature that distinguishes $S$. aromothyella from $S$. berthae is the robust forearm in males. This character is related to the development of the $m$. flexor carpi radialis, and, as employed here, refers to a situation where the belly of the $m$. flexor carpi radialis is noticeably bulbous, instead of an almost flat strip. As discussed by Faivovich (2002), the variation in development of this muscle shows a continuum among the species of the $S$. catharinae group, but the difference between $S$. berthae and $S$. aromothyella is sufficient to distinguish them. The term hypertrophied 
forearm is equivalent to character 50.1 in Faivovich (2002), that is, a situation where the $m$. flexor carpi radialis is so enlarged that its insertion is contiguous with the distal portion of the $m$. coracobrachialis.

In addition to the female specimens reported here, there are four females (MACN 35263-64, 37120, 37126) were collected along a forest stream at the type locality during four seasons of fieldwork. These females are superficially similar to the type series and to the referred specimens; however, they differ in being noticeably darker and having nostrils more protruded. It is still uncertain whether they are simply darker females of $S$. aromothyella or a different species.

Although two paratopotypes were collected along a stream in the forest, S. aromothyella, like $S$. berthae, is common in open areas around permanent or semipermanent water bodies. In this respect, they differ from many other species in the S. catharinae group, which are most common inside the forest (Almeida and Cardoso, 1985; Pombal et al., 1995).

Acknowledgments.-I thank J. P. Pombal, Jr. for allowing me to examine a specimen of the BMNH on loan to him; C. W. Myers, J. P. Pombal, Jr., T. Grant, D. R. Frost, A. Kwet, and P. C. A. Garcia for comments on the manuscript; F. Fernandez for access and logistical support in the type locality; and G. Lenglet (IRSNB), G. R. Carrizo (MACN), J. P. Pombal, Jr. and U. Caramaschi (MNRJ), H. Zaher, P. E. Vanzolini and M. T. Rodrigues (MZUSP), C. F. B. Haddad (CFBH), A. Giaretta (ZUEC), S. P. de Carvalho e Silva and M. d. R. Gomes (ZUFRJ) for loan of specimens and providing work space. A. C. de Queiroz Carnaval and S. P. de Carvalho e Silva authorized me to cite information from their unpublished theses. D. Arrieta D. Baldo, J. C. Baciluk, M. K. Evia, and M. Ponssa were excellent companions in the field. L. Peresan made the illustrations and T. Grant took the photographs. The American Museum of Natural History, the Department of Ecology, Evolution, and Environmental Biology/Columbia University, and NSF DEB-0407632 provided financial support during this project.

\section{Literature Cited}

Almeida, C. G., ANd A. J. Cardoso. 1985. Variabilidade em medidas dos espermatozóides de Hyla fuscovaria (Amphibia, Anura) e seu significado taxonômico. Revista Brasileira de Biologia 45:387-391.

Andrade, G. V., and A. J. Cardoso. 1987. Reconhecimento do grupo rizibilis: descrição de uma nova espécie de Hyla (Amphibia, Anura). Revista Brasileira de Zoologia 3:433-440

—. 1991. Descrição de larvas e biologia de quatro espécies de Hyla (Amphibia, Anura). Revista Brasileira de Biologia 51:391-402.
Barrio, A. 1964. Characteristics of Hyla berthae (Amphibia: Salientia). Copeia 1964:583-585.

Bokermann, W. C. A. 1967. Dos nuevas especies de Hyla del grupo catharinae (Amphibia, Hylidae). Neotropica 13:61-66.

Bokermann, W. C. A., and I. Sazima. 1973. Anfíbios da Serra do Cipó, Minas Gerais, Brasil. 1: Duas espécies novas de Hyla (Anura, Hylidae). Revista Brasileira de Biologia 33:521-528.

Caramaschi, U., and G. Kisteumacher. 1989. Duas novas espécies de Ololygon Fitzinger, 1843, do sudeste do Brasil (Amphibia, Anura, Hylidae). Boletim do Museu Nacional, Nóva Serie, Zoolgia 327:1-15.

Cardoso, A. J., and C. F. B. Haddad. 1982. Nova espécie de Hyla da Serra da Canastra (Amphibia, Anura, Hylidae). Revista Brasileira de Biologia 42:499-503.

Carnaval, A. C. D. Q. 1997. Aspectos da morfologia e biologia reprodutiva de uma população de Scinax argyreornatus em Magé, no Estado do Rio de Janeiro (Amphibia, Anura, Hylidae). Master's Thesis, Universidade Federal do Rio de Janeiro, Rio de Janeiro, Brazil.

Carvalho e Silva, S. P. 1994. Espécies do gênero Scinax, do grupo "catharinae" (Amphibia, Anura, Hylidae). Ph.D. Dissertation, Universidade de São Paulo, São Paulo, Brazil.

Cochran, D. M. 1955. Frogs of southeastern Brazil. Bulletin of the United States National Museum 206:1-423.

Cruz, C. A. G., and O. L. Peixoto. 1982. Uma nova espécie de Hyla do Espírito Santo, Brasil (Amphibia, Anura, Hylidae). Revista Brasileira de Biologia 42: 721-724.

De la Riva, I., J. Köhler, S. Lötters, and S. Reichle. 2000. Ten years of research on Bolivian amphibians: updated checklist, distribution, taxonomic problems, literature and iconography. Revista Española de Herpetología 14:19-164.

Duellman, W. E. 1970. Hylid frogs of Middle America. Monographs of the Museum of Natural History, University of Kansas 1-2:1-753.

Faivovich, J. 2002. A cladistic analysis of Scinax (Anura: Hylidae). Cladistics 18:367-393.

Frost, D. R. 2002. Amphibian Species of the World. V2.21 (15 July 2002). Available at http://research.amnh.org/ herpetology/amphibia/index.html.

Haddad, C. F. B., and J. P. Pombal, JR. 1987. Hyla hiemalis, nova espécie do grupo rizibilis do Estado de São Paulo (Amphibia, Anura, Hylidae). Revista Brasileira de Biologia 47:127-132.

KwEt, A. 2001. Südbrasilianische Laubfrösche der Gattung Scinax mit Bemerkungen zum Geschlecht des Gattungsnamens und zum taxonomischen Status von Hyla granulata Peters, 1871. Salamandra 37:211-238.

Kwet, A., And M. Di-Bernardo. 1999. Pró-Mata Anfíbios. Amphibien. Amphibians. EDIPUCRS, Porto Alegre, Brazil.

Langone, J. A., and C. M. Prigioni. 1988. Nuevas contribuciones a la distribución geográfica de Hyla berthae Barrio, 1962 (Anura, Hylidae). Boletín Sociedad Zoológica del Uruguay (2a Época) 4:1-4.

Lopez, C. A., B. L. Blotto, and P. M. Cacivio. 1999. Tres nuevos anfibios para la provincia del Chaco (Anura: Hylidae y Leptodactylidae). Cuadernos de Herpetología 13:105-106. 
Lutz, B. 1973. Brazilian Species of Hyla. University of Texas Press, Austin, Texas.

Myers, C. W., and W. E. Duellman. 1982. A new species of Hyla from Cerro Colorado, and other tree frog records and geographical notes from Western Panama. American Museum Novitates 2752:1-32.

Pombal, J. P., JR., R. P. Bastos, and C. F. B. Haddad. 1995. Vocalizações de algumas espécies do gênero Scinax (Anura, Hylidae) do sudeste do Brasil e comentários taxonômicos. Naturalia 20:213-225.

Pombal, J. P., JR., And M. Gordo. 1991. Duas novas espécies de Hyla da Floresta Atlântica no Estado de São Paulo (Amphibia, Anura). Memórias do Instituto Butantan 53:135-144.

Savage, J. M., and W. R. Heyer. 1967. Variation and distribution in the tree-frog genus Phyllomedusa in Costa Rica, Central America. Beiträge zur Neotropischen Fauna 5:111-131.

VARELA, E. A. 1999. Tipos de la colección herpetológica del Museo Argentino de Ciencias Naturales "Bernardino Rivadavia”, Buenos Aires, Argentina. Iheringia, Série Zoologia. 87:57-74.

Accepted: 23 August 2004

Associate Editor: Joseph Mendelson III

\section{APPENDIX I}

Additional Specimens Examined

Scinax agilis: CFBH 1942, 1944; S. albicans: MZUSP 69250-52; S. angrensis: ZUFRJ 2867-69, 5144, 5170; S. argyreornatus: MNRJ 114 (lectotype), CFBH 1283, 1292 , 1298; S. ariadne: AMNH 78229 (paratype); S. berthae: LIH 1080 (holotype), MACN 36983-85, 36989-98, 37241-57; S. brieni: IRSNB 1027 (holotype), MACN 16994-95 (topotypes); S. canastrensis: ZUEC 4188-91, 4193 (paratypes); S. carnevalli: MZUSP 61045-48 (paratypes); S. catharinae: BMNH 1947.2.1266 (syntype); S. centralis: CFBH 2640-44 (paratypes); S. flavogutattus: MZUSP 53335-43; S. heyeri: CFBH 1041; S. hiemalis: MZUSP 60555 (holotype), 60556-57 (paratypes); S. humilis: MNRJ 2248 (holotype), 1478 (paratotype), ZUFRJ 2242-43, 3133-34, 7503; S. jureia: MZUSP 74209, 74237-38 (paratypes); S. littoralis: MZUSP 73736-38 (paratypes); S. longilineus: ZUEC 4340, 760709, 7614 (topotypes); S. luizotavioi: MZUSP 61043-44 (paratypes); S. machadoi: AMNH 88645-46 (paratypes); $S$. rizibilis: MZUSP 73660 (holotype); S. obtriangulatus: MZUSP 107834-107835, 107839-40; S. trapicheiroi: MZUSP 3431, 3444, 3447, 3372; S. ranki: MZUSP 59540 (holotype), 59241-42 (paratype). 


\title{
A NEW SPECIES OF IGUANIAN LIZARD (STENOCERCUS) FROM THE WESTERN LOWLANDS OF SOUTHERN ECUADOR AND NORTHERN PERU
}

\author{
OMAR TORRES-CarvajaL ${ }^{1,2}$ \\ Department of Vertebrate Zoology, National Museum of Natural History, Smithsonian Institution, \\ Washington, DC 20560, USA
}

\begin{abstract}
I describe a new species of Stenocercus from the lowlands of southwestern Ecuador and northwestern Peru. The new species differs from other Stenocercus by the combination of the following characters: posterior circumorbitals present, one row of supraoculars enlarged, posterior head scales enlarged, projecting angulate temporals absent, canthals two, ventrals smooth, posthumeral and postfemoral mite pockets shallow, dorsolateral crests absent, inscriptional ribs not articulating midventrally, throat yellow and venter lavender in males. Some evidence suggests that the new species is closely related to Stenocercus iridescens, which occurs allopatrically in the lowlands of western Ecuador and southwestern Colombia.
\end{abstract}

Key words: Ecuador; Iguania; New species; Peru; Stenocercus; Systematics

With MORE than 50 species, Stenocercus Duméril and Bibron (1837) constitutes one of the most speciose squamate genera of South America. Most species of Stenocercus (Tropiduridae sensu Frost et al., 2001; Iguanidae sensu Macey et al., 1997) occur in the Andes from northern Colombia to central Argentina, with some exceptions such as $S$. dumerilii, which is known from eastern Para, Brazil (Avila-Pires, 1995). These lizards occupy a variety of habitats (e.g., dry and humid tropical forests, montane forests, paramo) at elevations of $0-4000 \mathrm{~m}$.

Approximately one-fifth of the species of Stenocercus have been described during the last 15 years (Cadle, 1991, 1998, 2001; AvilaPires, 1995; Torres-Carvajal, 2000). One of the main causes of this dramatic recent increase in the number of known species is that collections are being made in previously unexplored areas throughout the Andes (e.g., Lehr, 2002). Another reason is that existing collections have not been carefully examined. Hence, it is very likely that a considerable number of new

\footnotetext{
${ }^{1}$ Present Adpress: Natural History Museum and Biodiversity Research Center, and Department of Ecology and Evolutionary Biology, Dyche Hall-1345 Jayhawk Boulevard, The University of Kansas, Lawrence, KS 66045-7561, USA.

${ }^{2}$ Correspondence: e-mail, otorres@ku.edu
}

species will be described in the near future. Herein, I describe a new species of Stenocercus discovered in a previously unexplored forest of the western Andean slopes of southern Ecuador, and reassign specimens identified as S. iridescens in existing collections from northwestern Peru (Cadle, 1991).

\section{Materials and Methods}

Most type specimens of the new species were collected in Ecuador and are deposited in the Museo de Zoología, Pontificia Universidad Católica del Ecuador, Quito (QCAZ). Museum abbreviations of other type specimens follow Leviton et al. (1985). Specimens of S. iridescens examined in this study are listed in TorresCarvajal (2000), with additional specimens listed in Appendix I. Snout-vent length (SVL) and tail length (TL) were taken with a ruler and recorded to the nearest $1 \mathrm{~mm}$. All other measurements were made with digital calipers and recorded to the nearest $0.1 \mathrm{~mm}$. Osteological characters were examined from $\mathrm{x}$ ray radiographs and from a cleared-anddouble-stained adult female (QCAZ 6720). Sex was determined by noting the presence of hemipenes or sexually dichromatic characters. Eggs were incubated in a terrarium at 25-28 C. Egg volume was calculated with the prolate spheroid formula: $\mathrm{V}=4 / 3 \pi$ (length/2)(width/ 
$2)^{2}$. Descriptions and illustrations were prepared with the aid of a stereomicroscope equipped with a camera lucida. I follow the terminology of Cadle (1991) and TorresCarvajal $(2000,2004)$ for characters included in the description.

\section{Systematics}

\section{Stenocercus puyango sp. nov.}

Holotype.-QCAZ 6723, an adult male, from Puyango $\left(03^{\circ} 53^{\prime} \mathrm{S}\right.$, 80 $04^{\circ} 47^{\prime \prime} \mathrm{W}$, $300 \mathrm{~m}$ ), Provincia El Oro, Ecuador, collected on 7 January 2004 by Martha C. CarvajalAguirre and Omar Torres-Carvajal.

Paratypes.-ECUADOR: QCAZ 6355, from $19 \mathrm{~km}$ N Alamor, Provincia El Oro, collected on 28 March 2003 by Martín Bustamante and Italo G. Tapia; QCAZ 6356, from Bosque Protector Puyango $\left(3.88^{\circ} \mathrm{S}, 80.083^{\circ} \mathrm{W}\right)$, Provincia El Oro, collected on 28 March 2003 by Martín Bustamante and Italo G. Tapia; QCAZ 6701-6703, 6705-6713, same data as holotype except collected on 6 January 2004; QCAZ 67156722 , 6724, 6725, same data as holotype; AMNH 21934-36, from Río Puyango, collected on 12 October 1921 by G. H. H. Tate; PERU: MVZ 82364, from $21 \mathrm{~km} \mathrm{E,} 7 \mathrm{~km} \mathrm{~N}$ Olmos, 1310 m, Departamento Lambayeque, collected on 16 August 1967 by R. Huey; LSUMZ 26989, from Rica Playa, Río Tumbes, Departamento Tumbes, collected on 30 October 1973 by D. A. Tallman; KU 219834, from Matapalo, 90 m, Departamento Tumbes, collected on 12 January 1991 by Eric R. Wild; LSUMZ 39443, 39445-47, 39451, from Quebrada Faical, E El Caucho, 24 km SE Pampa de Hospital, 400 m, Departamento Tumbes, collected between 21-27 June 1979 by T. S. Schulenberg; AMNH 22186, no locality data.

Diagnosis.-(1) Maximum total length in males $309 \mathrm{~mm}(n=14)$; (2) maximum total length in females $265 \mathrm{~mm}(n=11)$; (3) vertebrals 42-50; (4) paravertebrals 43-53; (5) scales around midbody $30-45$; (6) supraoculars 4-6; (7) internasals 2-3; (8) postrostrals 4; (9) loreals 2-4; (10) gulars 18-22; (11) lamellae on Finger IV 15-20; (12) lamellae on Toe IV 2227; (13) posthumeral pocket shallow, Type 2 of Cadle (1991); (14) postfemoral pocket shallow, Type 5 of Cadle (1991); (15) parietal eye usually visible; (16) occipital scales large, smooth, imbricate; (17) projecting angulate temporals absent; (18) enlarged supraoculars occupying most of supraocular region in one row; (19) scales on frontonasal region weakly imbricate anteriorly; (20) preauricular fringe short; (21) neck folds absent; (22) lateral and dorsal nuchals similar in size; (23) posterior gulars in adults smooth, imbricate, not mucronate, not notched; (24) lateral and dorsal body scales similar in size; (25) vertebral crest prominent; (26) dorsolateral crest absent; (27) ventrals in adults smooth, imbricate, not mucronate; (28) scales on posterior surfaces of thighs keeled, imbricate, mucronate; (29) prefemoral fold absent; (30) inguinal groove absent; (31) preanals projected; (32) tail strongly compressed laterally in adult males; (33) tail length 68-73\% of total length; (34) caudal whorls per autotomic segment three; (35) caudals not spinose; (36) dark stripe extending anterodorsally from subocular region to supraciliaries in females and some males; (37) gular region of adult females black or densely pigmented; (38) gular region of adult males not black; (39) black blotch on ventral surface of neck in adult males usually present; (40) thin black or dark brown midventral line present; (41) black patch on ventral surface of thighs absent; (42) background color of dorsum in females and males dark brown; (43) postxiphisternal inscriptional ribs not articulating midventrally.

From all species of Stenocercus, S. puyango is similar to those species included in the "Ophryoessoides group" (Cadle, 2001) in having an enlarged row of supraocular scales and large posterior head scales. However, $S$. puyango differs from species in the "Ophryoessoides group", except S. iridescens, by having smooth head scales and smooth ventrals (slightly keeled in some juveniles and subadults). The only two other species of the "Ophryoessoides group" with relatively smooth head scales-S. aculeatus and S. fimbriatus - have strongly keeled ventrals. Stenocercus puyango is distinguished from S. iridescens (character states in parentheses) by having a shallow postfemoral pocket (postfemoral pocket absent), posterior circumorbitals (posterior circumorbitals generally absent, observed only in $4 \%$ of the specimens examined), and by lacking inscriptional ribs that articulate midventrally (three pairs of postxiphisternal inscriptional ribs articulate midventrally) and black marks around tympanum 

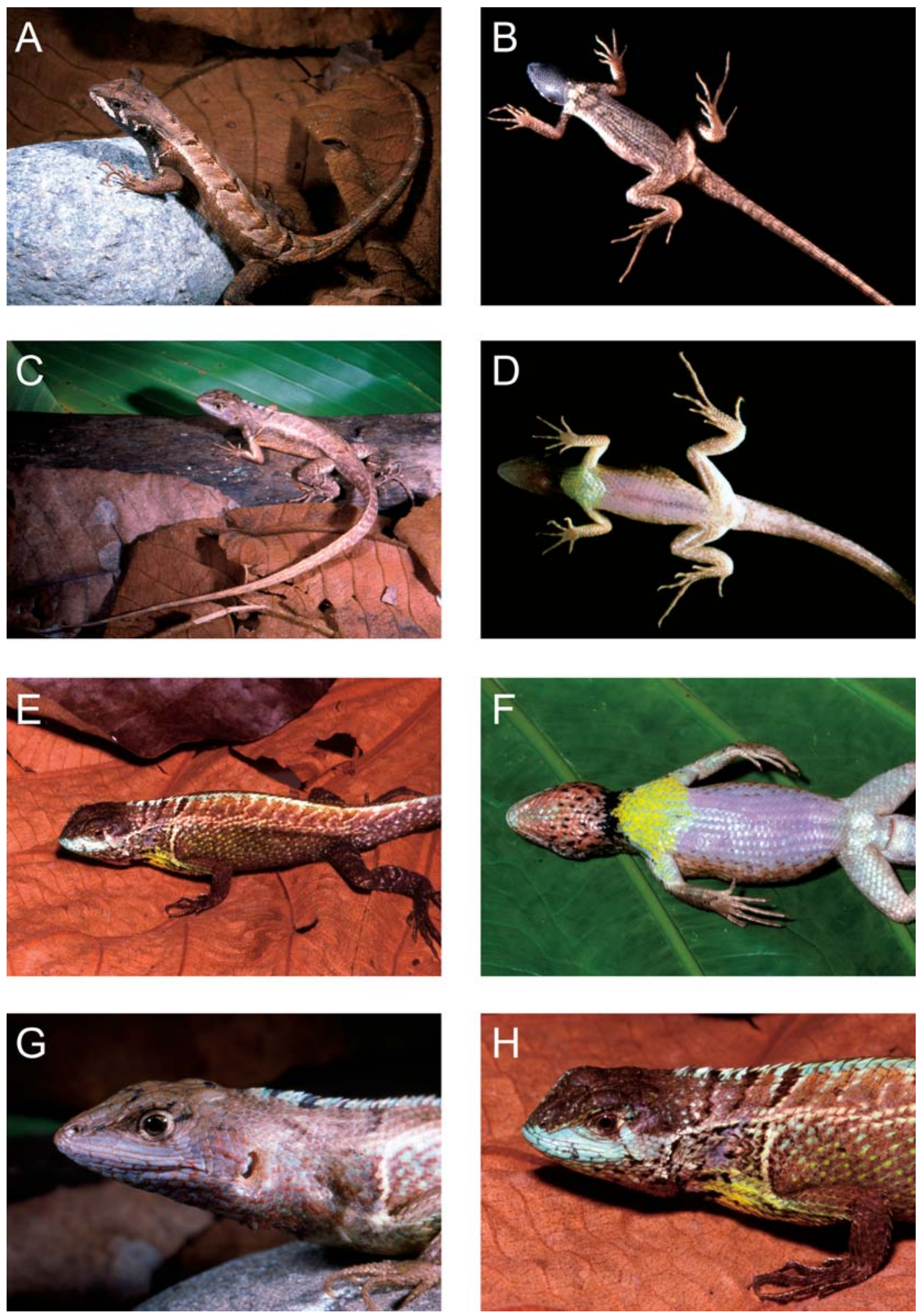
TABLE 1.-Summary of morphological characters, measurements ( $\mathrm{mm}$ ), and color patterns of Stenocercus iridescens, S. limitaris, and S. puyango. Range followed by mean \pm standard deviation, or range followed by mode are given for quantitative characters. Data for S. iridescens and S. limitaris are from Torres-Carvajal (2000) and Cadle (1998), respectively.

\begin{tabular}{|c|c|c|c|}
\hline Character & $\begin{array}{l}\text { S. iridescens } \\
\quad n=42\end{array}$ & $\begin{array}{l}\text { S. limitaris } \\
n=44\end{array}$ & $\begin{array}{l}\text { S. puyango } \\
n=33\end{array}$ \\
\hline \multirow[t]{2}{*}{ Scales around midbody } & $35-52$ & $39-54$ & $30-45$ \\
\hline & $41.57 \pm 3.31$ & $47.30 \pm 3.16$ & $41.06 \pm 2.78$ \\
\hline \multirow[t]{2}{*}{ Vertebrals } & $40-52$ & $40-52$ & $42-52$ \\
\hline & $45.31 \pm 3.22$ & $45.70 \pm 2.54$ & $46.38 \pm 2.62$ \\
\hline \multirow[t]{2}{*}{ Gulars } & $16-20$ & $17-23$ & $18-22$ \\
\hline & $18.19 \pm 1.09$ & $20.10 \pm 1.28$ & $19.00 \pm 1.17$ \\
\hline \multirow[t]{2}{*}{ Supraoculars } & $2-5$ & $3-5$ & $4-6$ \\
\hline & 3 & 4 & 4 \\
\hline \multirow[t]{2}{*}{ Internasals } & $2-4$ & $4-5$ & $2-4$ \\
\hline & 2 & 4 & 2 \\
\hline \multirow[t]{2}{*}{ Subdigitals Finger IV } & $15-18$ & $17-23$ & $15-20$ \\
\hline & $15.90 \pm 0.89$ & $19.70 \pm 1.26$ & $16.64 \pm 1.32$ \\
\hline \multirow[t]{2}{*}{ Subdigitals Toe IV } & $22-28$ & $24-32$ & $22-27$ \\
\hline & $24.73 \pm 1.57$ & $27.50 \pm 1.93$ & $24.70 \pm 1.45$ \\
\hline \multirow[t]{3}{*}{ Tail length/total length } & $0.62-0.68$ & $0.66-0.71$ & $0.68-0.73$ \\
\hline & $0.66 \pm 0.01$ & $0.69 \pm 0.01$ & $0.70 \pm 0.01$ \\
\hline & $n=30$ & $n=16$ & $n=25$ \\
\hline Maximum SVL males & 99 & 97 & 108 \\
\hline Maximum SVL females & 78 & 82 & 82 \\
\hline Posthumeral pocket & shallow & deep & shallow \\
\hline Postfemoral pocket & absent & deep & shallow \\
\hline Dorsal head scales & smooth & $\begin{array}{l}\text { keeled, wrinkled, } \\
\text { or multicarinate }\end{array}$ & smooth \\
\hline Posterior circumorbitals & absent & present & present \\
\hline Keeled angulate temporal & absent & present & absent \\
\hline Ventral scales in adults & $\begin{array}{l}\text { smooth or } \\
\text { slightly keeled }\end{array}$ & $\begin{array}{l}\text { strongly keeled, } \\
\text { mucronate }\end{array}$ & smooth \\
\hline Throat color in adult males & yellow & unknown & yellow \\
\hline Venter color in adult males & lavender & unknown & lavender \\
\hline
\end{tabular}

or posterior gular region in males (males with small black irregular marks on posterior gular region and around tympanum, Fig. 1). Measurements, scutellation, and other morphological characters of Stenocercus puyango are presented in Table 1.

Description of holotype.-Male; SVL $=88$ $\mathrm{mm}$; $\mathrm{TL}=198 \mathrm{~mm}$; maximum head width $=$ $16.2 \mathrm{~mm}$; head length $=20.6 \mathrm{~mm}$; head height $=14.7 \mathrm{~mm}$; occipitals, parietals, interparietal, and postparietals large, smooth, slightly imbricate (Fig. 2); parietal eye visible; supraoculars in five rows, smooth, slightly imbricate, with one row more than three times larger than adjacent rows; anterior and poste- rior circumorbitals smooth, imbricate; canthals two; anteriormost canthal separated from nasal by two tiny scales; scales in frontonasal region slightly imbricate; internasals two; postrostrals four, wider than long; supralabials four; infralabials five; loreals three; lorilabials in one row; preocular not divided, in contact with posterior canthal; lateral temporals imbricate, slightly keeled; gulars in 19 rows between tympanic openings; all gulars smooth, imbricate, each bearing one apical pit; second infralabial in contact with first three sublabials; mental in contact with first pair of infralabials and first pair of postmentals; dorsal and lateral scales of body and neck keeled, imbricate;

FIG. 1.-(A-B) Stenocercus puyango, paratype, QCAZ 6721, female, $65 \mathrm{~mm}$ SVL (LAC); (C-D, G) S. puyango, holotype, QCAZ 6723, male, 88 mm SVL (LAC); (E, H) S. iridescens, MCZ 156849, male, $85.7 \mathrm{~mm}$ SVL (KIM); (F) S. iridescens, USNM 285780, male, $88 \mathrm{~mm}$ SVL (RWM). 
scales around midbody 41; vertebrals large, in 48 rows, forming a prominent serrate vertebral crest; paravertebrals 49; ventrals smooth, imbricate; preauricular fringe short, composed of three enlarged scales, of which the ventralmost is largest; neck and body folds absent; limb scales keeled, imbricate; ventral scales of hind limbs smooth or slightly keeled; lamellae on Finger IV 17; lamellae on Toe IV 24; tail strongly compressed; caudals keeled, imbricate; basal subcaudals smooth, imbricate; vertebral crest extending more than half length of tail; tail length 2.2 times SVL; posthumeral pocket shallow with wide opening and lined with tiny scales (Type 2 of Cadle, 1991); postfemoral pocket shallow with slit-like opening (Type 5 of Cadle, 1991); two xiphisternal and two long postxiphisternal pairs of inscriptional ribs that do not articulate midventrally (Pattern 1A of Torres-Carvajal, 2004).

Color in life of holotype.-Dorsum light brown with darker chevrons over vertebral line; distinct dark brown chevron on suprascapular region; cream line extending vertically from shoulder to dorsolateral part of body; subocular and loreal regions cream; dark brown interorbital bar, wider between semicircles; occipital region with two black blotches; gular region rosy; borders of infralabials, sublabials, postmentals, mental, and anterior gulars with irregular light red marks; posterior gular region, and ventral and lateral sides of neck with tiny red marks aligned longitudinally; black blotch on ventromedial aspect of neck; throat bright yellow; ventral surface of body between pectoral and pelvic girdles lavender with a faint, narrow dark midventral line; flanks of body with tiny red marks between fore limbs and hind limbs (Fig. 1).

Variation.-Sexual variation in measurements and scutellation of Stenocercus puyango is presented in Table 2. Posterior circumorbitals are absent in $9 \%$ of the specimens and number of loreals varies from 2-4 (mode $=2)$. The second infralabials are not in contact with the third sublabials in $39 \%$ of the specimens, and the ventrals are slightly keeled in two adult males. A dark red or black patch is present on the ventromedial aspect of the neck in most males (69\%), whereas an oblique subocular dark band is absent in $25 \%$ of the specimens.

An adult female (QCAZ 6702) had the following coloration in life: dorsum dark brown
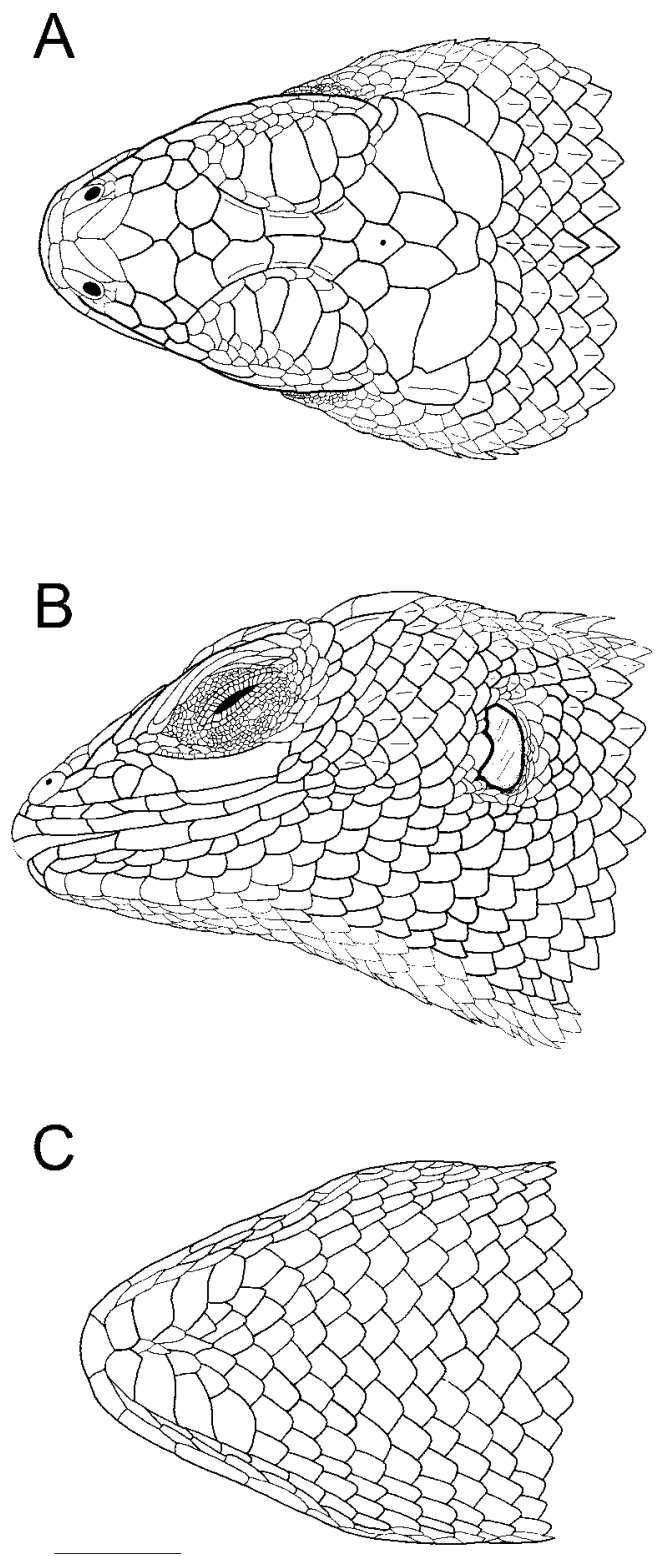

FIG. 2.-Stenocercus puyango, QCAZ 6723, male (holotype). (A) Dorsal, (B) lateral, and (C) ventral views of the head. Scale bar $=5 \mathrm{~mm}$.

with darker chevrons over vertebral line; cream line extending longitudinally from subocular region, through dorsal border of tympanum, to level of insertion of forelimbs; another cream line extending vertically from the former to shoulder; subocular and loreal regions white cream; posteroventrally oriented dark brown band on subocular region; dark brown 
TABLE 2.-Sexual variation in scutellation and measurements (mm) of Stenocercus puyango. Range (first line), mean \pm standard deviation (second line), and $n$ (third line)

\begin{tabular}{|c|c|c|}
\hline Character & Males & Females \\
\hline \multirow{3}{*}{$\begin{array}{l}\text { Scales around } \\
\text { midbody }\end{array}$} & $38-45$ & $30-45$ \\
\hline & $41.68 \pm 1.99$ & $40.56 \pm 3.41$ \\
\hline & 16 & 16 \\
\hline \multirow[t]{2}{*}{ Vertebrals } & $42-50$ & $43-52$ \\
\hline & $\begin{array}{c}46.37 \pm 2.52 \\
16\end{array}$ & $\begin{array}{c}46.66 \pm 2.64 \\
15\end{array}$ \\
\hline \multirow[t]{3}{*}{ Gulars } & $18-22$ & $18-21$ \\
\hline & $19.19 \pm 1.17$ & $18.87 \pm 1.20$ \\
\hline & $\begin{array}{c}16 \\
4-6\end{array}$ & $\begin{array}{c}16 \\
4-5\end{array}$ \\
\hline \multirow{2}{*}{ Supraoculars } & $4.75 \pm 0.68$ & $4.37 \pm 0.5$ \\
\hline & 16 & 16 \\
\hline \multirow[t]{2}{*}{ Internasals } & $2-4$ & $2-4$ \\
\hline & $\begin{array}{c}2.18 \pm 0.54 \\
16\end{array}$ & $\begin{array}{c}2.62 \pm 0.88 \\
16\end{array}$ \\
\hline \multirow{3}{*}{$\begin{array}{l}\text { Subdigitals } \\
\text { Finger IV }\end{array}$} & $15-20$ & $15-18$ \\
\hline & $17.06 \pm 1.44$ & $16.31 \pm 1.08$ \\
\hline & 16 & 16 \\
\hline \multirow{3}{*}{$\begin{array}{l}\text { Subdigitals } \\
\text { Toe IV }\end{array}$} & $23-27$ & $22-27$ \\
\hline & & \\
\hline & $\begin{array}{c}25.00 \pm 1.26 \\
16\end{array}$ & $\begin{array}{c}24.56 \pm 1.50 \\
16\end{array}$ \\
\hline \multicolumn{3}{|l|}{ Tail length/total } \\
\hline \multirow[t]{3}{*}{ length } & $0.68-0.73$ & $0.68-0.70$ \\
\hline & $0.71 \pm 0.01$ & $0.69 \pm 0.01$ \\
\hline & 12 & 8 \\
\hline Maximum SVL & 108 & 82 \\
\hline
\end{tabular}

interorbital bar; gular region and neck dark brown; ventral surfaces of body, limbs, and tail cream with dark brown flecks; 8-shaped dark brown mark on throat; thin dark brown midventral stripe between 8-shaped mark and vent; three large cream blotches on posterior surface of each thigh. Other females have similar color patterns (Fig. 1).

Juvenile males (QCAZ 6701, 6703) also have yellow throats, but they differ from adult males in having dark throat marks similar to those observed in females. However, these throat marks are faint, which suggests that the neonatal throat pattern is retained in females and modified in adult males.

Natural history.-Specimens were active between 1000-1600 h. Whereas juveniles and some adult females were found on leaf litter, adult males and some females were found on rocks or logs exposed to the sun. Several adult males were observed doing push-up displays. An adult female (QCAZ 6721) laid two eggs

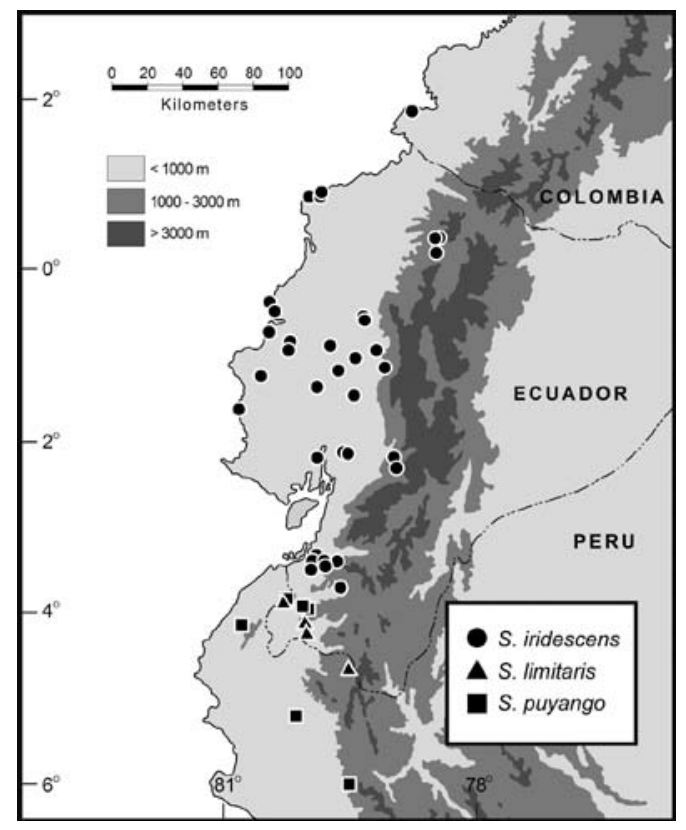

FIG. 3.-Distribution of Stenocercus puyango, $S$. iridescens, and S. limitaris.

in captivity on 10 January 2004 . The sizes of these eggs were $17.29 \mathrm{~mm} \times 8.72 \mathrm{~mm}$ and $17.42 \mathrm{~mm} \times 8.73 \mathrm{~mm}$; their volumes were $688.38 \mathrm{~mm}^{3}$ and $695.14 \mathrm{~mm}^{3}$, respectively. After 96 days, a $0.7 \mathrm{~g}$ neonate $(\mathrm{SVL}=26.7$ $\mathrm{mm}, \mathrm{TL}=54.7 \mathrm{~mm}$ ) hatched from one of the eggs.

Distribution and ecology.-Stenocercus puyango inhabits lowland deciduous forests of the western slopes of the Andes in southern Ecuador and northern Peru (Fig. 3). It occurs at elevations of $90-1500 \mathrm{~m}$ in Provincia El Oro (Ecuador) and Departamentos Tumbes, Piura, and Lambayeque (Peru). Stenocercus puyango is sympatric with $S$. limitaris at Quebrada Faical in Departamento Tumbes, Peru (Cadle, 1998). It is very likely that these two species are sympatric at other localities in southwestern Ecuador and northwestern Peru as well. One of the paratypes (QCAZ 6355) of $S$. puyango was collected close to Alamor (Provincia Loja, Ecuador), where both $S$. limitaris and S. carrioni occur (Cadle, 1998; Fritts, 1974).

Etymology.-The specific name is a noun in apposition and refers to the Puyango Protected Forest, where the holotype of this species was collected. This 2658 ha reserve in southwest- 
ern Ecuador has one of the world's largest collections of petrified tree trunks, on which several adult males and females of the new species were found.

Remarks.-Similarity in external morphology and color patterns (Fig. 2), as well as adjacent geographical distribution (Fig. 3), suggest that the new species is closely related to S. iridescens (Table 1). Günther (1859) described $S$. iridescens as having smooth or very indistinctly keeled ventrals, but there seems to be some confusion concerning the degree of keeling of ventral scales in this species (e.g., Cadle, 1998, 2001; Fritts, 1974). Similar to other species of Stenocercus (e.g., S. festae), there is ontogenetic variation in the degree of keeling of the ventral scales in S. iridescens. Juveniles have keeled ventrals, which become less keeled or smooth in adulthood.

Stenocercus limitaris is another species with enlarged head scales that occurs in the lowlands of southwestern Ecuador and northwestern Peru in sympatry with $S$. puyango. The main differences between these two species (Table 1) are that $S$. limitaris has keeled dorsal head scales, a strongly keeled angulate temporal, strongly keeled and mucronate ventrals, and deep posthumeral and postfemoral pockets (Cadle, 1998).

Before Frost (1992) synonymized Ophryoessoides and Proctotretus with Stenocercus, species of Stenocercus with enlarged posterior head scales, one row of enlarged supraoculars, keeled ventrals, and pairs of inscriptional ribs articulating midventrally were placed in Ophryoessoides (Fritts, 1974). Even recently the term "Ophryoessoides Group" has been proposed to refer to the species of Stenocercus that have the character states mentioned above (Cadle, 2001). However, the distribution of several morphological characters among species of Stenocercus, including those used by Fritts (1974) to diagnose Ophryoessoides, suggest that Ophryoessoides is not a natural taxon (Frost, 1992). Stenocercus puyango is an example of a species with some but not all of the diagnostic characters of "Ophryoessoides". It has enlarged supraoculars and posterior head scales (Fig. 2), but it has smooth ventrals and its inscriptional ribs do not articulate midventrally. Without a hypothesis of phylogenetic relationships among species of
Stenocercus, the phylogenetic status of "Ophryoessoides" remains unclear.

\section{Resumen}

Describo una especie nueva de Stenocercus de tierras bajas del suroccidente ecuatoriano y noroccidente peruano. La especie nueva se distingue de otras especies de Stenocercus por la combinación de los siguientes caracteres: circumorbitales posteriores presentes, una hilera de escamas supraoculares ensanchada, escamas posteriores de la cabeza grandes, escamas temporales angulares no proyectadas, dos cantales, ventrales lisas, bolsillos posthumerales y postfemorales poco profundos, crestas dorsolaterales ausentes, articulación medioventral de costillas abdominales ausente, pecho amarillo y vientre rosado en machos. Algunos de estos caracteres sugieren que la especie nueva está cercanamente emparentada con Stenocercus iridescens, la cual está distribuida alopátricamente en las tierras bajas del occidente ecuatoriano y suroccidente colombiano.

Acknowledgments.-I thank M. Carvajal-Aguirre, E. Paredes, and the guards of Puyango Protected Forest for assistance in the field; C. Austin (LSUMZ), L. A. Coloma (QCAZ), K. de Queiroz (USNM), L. Ford and D. Frost (AMNH), J. D. Lynch (ICN), J. A. McGuire (MVZ), and L. Trueb (KU) for the loan of specimens; F. Ayala, M. Castañeda, and S. Gotte for their help with egg incubation, $\mathrm{x}$-ray radiographs, and clearing-and-double-staining, respectively; L. A. Coloma (LAC), K. I. Miyata (KIM), and R. W. McDiarmid (RWM) for the color photographs; E. Bonaccorso for assistance with GIS software; J. Rosado for data on MCZ 156849; K. de Queiroz and R. McDiarmid for comments and suggestions. This research was funded by a predoctoral fellowship from the Smithsonian Institution. 2003-2004 specimens were collected under permit 006-IC-FAU-DBAP/MA issued to the QCAZ by the Ministerio de Ambiente of Ecuador.

\section{Literature Cited}

Avila-Pires, T. C. S. 1995. Lizards of Brazilian Amazonia (Reptilia: Squamata). Nationaal Natuurhistorisch $\mathrm{Mu}-$ seum, Zoologische Verhandelingen 299:1-706.

Cadle, J. E. 1991. Systematics of lizards of the genus Stenocercus (Iguania: Tropiduridae) from northern Perú: new species and comments on relationships and distribution patterns. Proceedings of the Academy of Natural Sciences of Philadelphia 143:1-96.

1998. New species of lizards, genus Stenocercus (Iguania: Tropiduridae), from western Ecuador and Peru. Bulletin of the Museum of Comparative Zoology 155:257-297.

. 2001. A new species of lizard related to Stenocercus caducus (Cope) (Squamata: Iguanidae) from Peru and 
Bolivia, with a key to the "Ophryoessoides Group". Bulletin of the Museum of Comparative Zoology 157:183-222.

Duméril, A. M., And G. Bibron. 1837. Erpétologie Générale ou Histoire Naturelle Complète des Reptiles. Librairie Encyclopedique de Roret, Paris, France.

FritTs, T. H. 1974. A multivariate and evolutionary analysis of the andean iguanid lizards of the genus Stenocercus. San Diego Society of Natural History Memoir 7:1-89.

Frost, D. R. 1992. Phylogenetic analysis and taxonomy of the Tropidurus group of lizards (Iguania: Tropiduridae). American Museum Novitates 3033:1-68.

Frost, D. R., R. Etheridge, D. Janies, and T. A. Titus. 2001. Total evidence, sequence alignment, evolution of polychrotid lizards, and a reclassification of the Iguania (Squamata: Iguania). American Museum Novitates 3343:1-38.

Günther, A. 1859. Second list of the cold-blooded vertebrata collected by Mr. Fraser in the Andes of western Ecuador. Proceedings of the Zoological Society of London 1859:402-427.

Lehr, E. 2002. Amphibien Und Reptilien in Peru. Die Herpetofauna Entlang Des 10. Breitengrades Von Peru: Arterfassung, Taxonomie, Ökologische Bemerkungen Und Biogeographische Beziehungen. Natur und TierVerlag, Münster, Germany.

Leviton, A. E., R. H. Gibbs, JR., E. Heal, and C. E. Dawson. 1985. Standards in herpetology and ichthyology: part I. Standard symbolic codes for institutional resource collections in herpetology and ichthyology. Copeia 1985:802-832.

Macey, J. R., A. Larson, N. B. Ananjeva, and T. J. Papenfuss. 1997. Evolutionary shifts in three major structural features of the mitochondrial genome among iguanian lizards. Journal of Molecular Evolution 44:660-674.

Torres-Carvajal, O. 2000. Ecuadorian lizards of the genus Stenocercus (Squamata: Tropiduridae). Scientific Papers University of Kansas Museum of Natural History 15:1-38.
2004. The abdominal skeleton of tropidurid lizards (Squamata: Tropiduridae). Herpetologica 60:75-83.

Accepted: 17 September 2004

Associate Editor: Joseph Mendelson III

\section{APPENDIX I}

\section{Additional Specimens}

Stenocercus iridescens.-COLOMBIA: Narino: Tumaco, $1^{\circ} 47^{\prime} 55^{\prime \prime} \mathrm{N}, 78^{\circ} 48^{\prime} 56^{\prime \prime} \mathrm{W}, 0 \mathrm{~m}$, ICN 4225 ; ECUADOR: Imbabura: Apuela, $0^{\circ} 21^{\prime} 0^{\prime \prime} \mathrm{N}, 78^{\circ} 30^{\prime} \mathrm{W}$, USNM 200901; $1 \mathrm{~km}$ E Apuela, 1950 m, USNM 200902; 2 km NE Rio Apuela, 1950 m, USNM 200903-04; 0.5 km W Rio Apuela, 1860 m, USNM 200905-10; 2 km W Apuela, $1850 \mathrm{~m}$, USNM 200911; 1 km SW Peñaherrera, 1950-2000 m, USNM 200912-13; 3 km SW Peñaherrera, along trail between Apuela and García Moreno, $1825 \mathrm{~m}$, USNM 200914-17; 10 km S Peñaherrera, USNM 200918-19; Charguayacu USNM 200920; Los Riós: Centro Científico Río Palenque, $0^{\circ} 35^{\prime} \mathrm{S}, 79^{\circ} 22^{\prime} \mathrm{W}, 150-200 \mathrm{~m}$, USNM 285460-65; Hacienda El Triunfo, ca. $30 \mathrm{~km} \mathrm{~N}$ Vinces, $01^{\circ}$ $30^{\prime} \mathrm{S}, 79^{\circ} 40^{\prime} \mathrm{W}$, USNM 222800; Jauneche, $01^{\circ} 10^{\prime} \mathrm{S}, 79^{\circ}$ $40^{\prime} \mathrm{W}$, USNM 222801; $1 \mathrm{~km}$ E Jauneche, 40-70 m, USNM 285780-81; Quevedo, USNM 200921-34; Manabi: 12 km NNE Jipijapa, USNM 200935; $4 \mathrm{~km}$ W Calceta, USNM 200936-38; Junín USNM 200939; 2 km N San Clemente, USNM 200940; 9 km N San Vicente, 0 m, USNM 20094145; Guayas: Cuatro Hermanitos Experimental Station, NW of Guayaquil, USNM 200981; Estero de Soledad near Río Churute, $02^{\circ} 30^{\prime} \mathrm{S}, 79^{\circ} 44^{\prime} \mathrm{W}, 5 \mathrm{~m}$, USNM 222797-99; Milagro, $2^{\circ} 7^{\prime}$ S, $79^{\circ} 35^{\prime} 60^{\prime \prime} \mathrm{W}$, USNM 200982; Hacienda San Miguel, 5 km E Milagro, USNM 200983-88; 21 km SW El Empalme, USNM 200995-96; El Oro: 2 km S Pasaje, USNM 200946-54; 15 km E Pasaje, 100 m, USNM 200955; $7 \mathrm{~km} \mathrm{SE} \mathrm{Buena} \mathrm{Vista,} \mathrm{USNM} \mathrm{200956;} \mathrm{Machala,} \mathrm{USNM}$ 200957-58; 7 km SSE Machala, 20 m, USNM 200959-76, 222585; Santa Rosa, $3^{\circ} 27^{\prime} \mathrm{S}, 79^{\circ} 58^{\prime} \mathrm{W}$, USNM 200977-80. 